Article

\title{
Circular Economy and Economic Development in the European Union: A Review and Bibliometric Analysis
}

\author{
Vítor Domingues Martinho ${ }^{1, *}$ and Paulo Reis Mourão ${ }^{2}$ (D) \\ 1 Agricultural School (ESAV) and CERNAS-IPV Research Centre, Polytechnic Institute of Viseu (IPV), \\ 3504-510 Viseu, Portugal \\ 2 Department of Economics and NIPE, University of Minho, 4710-057 Braga, Portugal; paulom@eeg.uminho.pt \\ * Correspondence: vdmartinho@esav.ipv.pt
}

Received: 3 September 2020; Accepted: 18 September 2020; Published: 20 September 2020

check for updates

\begin{abstract}
Increased changes in the climate and ecosystems call for a sustainable economic development, where economic growth should be compatible with the environment goals. In order to do this, it is urgent to find new ways of life and new production systems that make our ecological footprint compatible with global sustainability. The concept of the circular economy has brought relevant contributions to this problem. The central objective of the study presented here is to highlight the main insights presented through scientific literature about the concept of the circular economy within the European Union. In practice, the intention is to show what has already been done about this topic and what can/should be implemented in the future. To achieve these objectives, 144 articles were considered from the Web of Science (Core Collection) for the topics "circular economy" and "European Union". These documents were, firstly, analysed through a proper literature review and later explored through bibliometric analysis, considering bibliographic data and the VOSviewer software. As the main findings have revealed, the increased importance of this concept within the European Union is recognized. However, this paper also identifies several challenges in the literature, namely the concentration of the identified publications in certain countries, organizations, and authors.
\end{abstract}

Keywords: sustainability; reuse; recycling; literature gaps

\section{Introduction}

The social, economic, environmental, and technological contexts, amongst others, change at a great velocity around the world, and these frameworks call for new concepts, approaches, and perspectives concerning how multiple stakeholders play their role in society and in economic activities. The concept of circular economy, especially in countries having great environmental impacts, appears to have its importance widely recognized among the policymakers and the scientific community. The number of scientific documents available on the main scientific platforms (WOS, for example) confirms this perspective [1,2].

In fact, the interest shown by the scientific community towards the topics related with the circular economy has increased over the last decades, namely, in domains related with the economy and management. This is highlighted by the number of publications from European, Chinese, and North American authors. On the other hand, new ecological concepts may be interlinked with other new concepts from other socioeconomic fields, such as innovation and entrepreneurship [1].

In any case, the topics associated with the circular economy seem to arouse great curiosity within the Chinese and the European Union scientific community, namely, after changes in related policy instruments [2]. These fields have motivated researchers around the world. On the other hand, it is worth stressing the diversity of realities within each country, as well as inside the European Union. Since the concerns around the circular economy are global, the opportunities and the potential to 
cooperate across nations is enormous, as well as the interlinkages among several scientific domains and the different dimensions of society [2].

In this perspective, the core objective of this study is to highlight the main insights related to the concept of circular economy in the specific context of the European Union, showing what has been researched and presenting what must be done in the future, outlining scientific and socioeconomic gaps. For this purpose, a total of 144 articles (excluding proceeding papers) were obtained, in December 2019, from the Web of Science Core Collection [3] for the topics "circular economy" and "European Union" considered simultaneously. These documents were first analysed considering literature review and later explored further through bibliometric analysis (bibliographic data), considering the VOSviewer [4] software. Other topics could be considered, such as bioeconomy, or green economy [1], or "*ircular* *econom*" to allow for a wider search [2]. However, considering the relevance of the concept "circular economy" to the European Union scientific community [1], the focus of this study was specifically on this topic ("circular economy").

A search on the Web of Science All Databases [5] shows that when it comes to the topics "circular economy", "European Union", and "bibliometric", simultaneously, there are only three documents; the research from Gregorio et al. [1] and Turkeli et al. [2], and a conference paper, revealing the potential of work to be explored in these fields. In turn, the research developed here has the novelty of being focused on the topics "circular economy" and "European Union", complementing the literature review of the 144 documents with the bibliometric analysis.

Bibliometric analyses have been considered by several authors from different scientific fields, as highlighted by Martinho [6,7] and Mourao and Martinho [8]. A relevant aspect in bibliometric analysis, is the choice of topics to perform the search on scientific platforms. As stressed before, many works have already been done for the "circular economy" domain, but there are still challenges emerging from searching simultaneously the terms "circular economy" and "European Union". In fact, as shown by Gregorio et al. [1] and Turkeli et al. [2], several search topics have already been considered in these domains, but here, considering the works as a basis, the aim is to explore the "circular economy" dimension in the "European Union". The 144 articles obtained from the Web of Science (WOS) platform were the only found in December 2019 for these two topics considered simultaneously. In this way, the conclusions obtained in this work are representative for these two domains.

In turn, the literature review performed in this research, complemented with the bibliometric analysis, follows authors such as Takey and Carvalho [9] and Xu et al. [10].

\section{The Rationale behind the Selection of the Topics "Circular Economy" and "European Union"}

There are several studies on the different dimensions related to the topic "circular economy" as shown, for example, by the researches of Gregorio et al. [1] and Turkeli et al. [2]. But there is still an opportunity to explore the researches about circular economy associated with the European Union context. In fact, the European Union framework is specific and has a great diversity between the different member-states, which creates relevant dimensions to be explored and analysed. On the other hand, the continuous changes in European policies and specifically the definition of an Action Plan for the Circular Economy, by the European Commission, make the European Union a fertile domain to be addressed. In this way, our aim is to bring insights from the literature about these domains through literature review and bibliometric analysis, considering, for instance, the developments of Takey and Carvalho [9] and $\mathrm{Xu}$ et al. [10].

The remaining sections of the paper are as follows. Section 2 revisits the most used keywords in the published materials about 'circular economy'. Section 3 details the exhaustive effort done in our bibliometric approach to the topic. Section 4 discusses the major findings and concludes the paper.

\section{Literature Review—Revisiting the Most Frequent Keywords around "Circular Economy"}

The literature was previously surveyed and analysed bibliometrically. This approach has its own contribution towards highlighting the main indicators from the scientific literature related with the 
topics addressed in this study. However, it was also possible to identify a set of dimensions that may be interesting to explore in the literature review, such as those related to management, efficiency, recycling, waste, innovation, and policies.

In this way, considering the insights obtained from the previous assessment, this section will be structured into the following subsections: Efficiency and sustainability; policies, governance, and management; product life cycle; resources and waste; innovation and opportunities; economic sectors; bio-economy. These topics were addressed because they were highlighted by the literature survey and bibliometric analysis as relevant in the domains related to the circular economy, but not significantly explored by the scientific literature as shown in the list for the co-occurrence keywords.

\subsection{Efficiency and Sustainability}

Sustainability, reuse, recycling, and integration have become current terms around the world, including the efficiency in the use of resources [11], namely in developed and developing countries, due to global warming and climate change [12]. In practice, the main objective of the multiple stakeholders is to promote economic growth [13] and competitiveness [14] without compromising the environment. One of the main challenges will be to provide societies with adjusted and sufficient resources [15]. The efficiency, productivity, and circular economy are, in general, viewed as interesting contributions for sustainable development; however, there are some specificities, namely macroeconomic, that should be considered more carefully [16]. In any case, more efficient resource utilization may bring about relevant outcomes for sustainability [17]. Quality of life and human health are, in general, interconnected with environmental sustainability [18], and there is a global concern with the environment [19], although sustainable developments are not easy goals [20]. The involvement of the several stakeholders may facilitate the evolution towards a greener economy and society [21], considering the great expectations in the European Union about the dimensions of the circular economy [22] and its local acknowledgement [23]. In this involvement, it is also important to understand the social dynamics [24]. Eco-efficiency is an aspect to take into account in the use of renewable sources of energy [25].

\subsection{Policies, Governance, and Management}

Public institutions, and their respective policies, play a determinant role in promoting a balanced relationship between socioeconomic activities and the environment, for example in the promotion of a renewable source of resource use [26]. In order to design efficient strategies, it is crucial to identify adjusted models [27] and indicators so as to perform pertinent assessments that support well-structured plans [28]. The indicators may be macro (country level), meso (industrial ecology), and micro (firm level) [29] and should be incorporated into the several policies, including regional strategies [30]. The discussion about the indicators to be considered so as to assess the circular economy is extensive [31]. Approaches which include the several institutions, the several levels of governance, and the complex policy framework, may bring to light relevant insights for policy design in an efficient evolution for a circular economy [32]. In this context, the European Union needs to rethink its policy framework for an effective decarbonisation [33], claiming, in some circumstances, for more robust frameworks [34]. This is also true for external cooperation, namely with developing countries [35]. For example, concerning the use of urban waste as agricultural fertilizers, the European legislation could be more specific about some aspects, namely those related with the potential contaminants [36]. The same deeper specificity could be helpful for plastics recyclers [37]. Another question concerning effective policy implementation is related with the unintended conflict amongst legislative instruments [38]. There is not yet, in fact, a consensus about the concept of circular economy [39], related strategies/options/alternatives [40], and methods for it to be properly assessed [41]. The policy dimension is one of the most important factors towards achieving levels of a circular economy [42], as well as, the governance dynamics and the respective adjustments [43]. Planned obsolescence is another question which legislation needs to address [44]. In general, the circular economy policies should address the following dimensions: Reuse, repair, and recycling; innovation; and promoting secondary material utilization [45]. The questions 
related with eco-design, fiscal policies, and public procurement should be addressed, and the obstacles should be explored for an effective policy implementation.

\subsection{Product Life Cycle}

The concept of circular economy has appeared these days from a perspective of increasing a product's life cycle through an approach of reuse, recirculation, and recycling [46], or reduce, reuse, and recycle [47]. This approach improves the efficiency of the resources used and promotes sustainable consumption models [48]. One of the greatest concerns related with product life cycles is related to plastic, due to the complexities associated with its composition [49], namely for the European Union [50]. A great part of plastic used is for packaging [51] and agro-food processes [52]. The production of plastic increased significantly in the last decades, and China is among the main polluters in this field [53]. The alternatives considered for packaging have, consequently, relationships with human health and sustainability [54]. Recovering aluminium is another concern with packaging [55]. The cascading use of waste, in some sectors, may be an interesting solution to mitigate the environmental impacts from the life cycle of some products [56]. Another example could be the use of plastic waste to be incorporated into transportation fuel production [57]. Another motive of concern is the electric and electronic waste [58], as a relevant challenge around the world [59] with a rapid increase in the European Union [60], or vehicles and tires [61], amongst the major sectors of the European economic activities [62], or lithium ion batteries [63,64], or the textile and clothing industry [65], or waste cooking oils [66], or baby diapers [67], or the forestry industry [68], or tablet, computer, and smartphone batteries [69]. A good end of life management mitigates the environmental impacts from the socioeconomic waste and residues [70].

\subsection{Resources and Waste}

The consideration of renewable resources for economic and social activities is determinant in order to decarbonise the planet [71], namely for energy inputs. In these cases, it is important, also, to minimize the environmental impacts from these alternatives [72]. The bio-based plastics may be an option for consideration in these contexts of renewable resources [73]. However, the increased stream of these products calls for further research into these alternatives, namely in terms of end of life [74]. The dependency of the European Union on raw materials from external markets is one further reason for an adjusted circular economy approach [75]. Only a small part of the waste materials produced are recycled around the world [76], and specifically in the Austrian context [77], sometimes caused by the use of waste and residues in bioenergy production [78]. This calls for adjusted measures, where waste reporting could provide its contribution [79]. In some contexts, the more efficient countries are, also, those with higher rates of recycling [80]. Recycling is, depending on the alternatives, always an interesting way to manage waste [81] from a sustainable perspective [82], as is reuse [83]. However, in these streams there are still some aspects that need more assessments [84] to make waste management and human health preservation compatible [85]. This is true across many dimensions of circular economy [86]. In these contexts, urban areas are those mainly responsible for solid waste generation [87], making solid municipal waste a real problem [88]. However, these are not the only sources [89] and the structure is diverse amongst different global regions [90], depending on their specific characteristics [91]. For example, Croatia recycled about $15 \%$ of its municipal solid waste [92]. In waste management, reuse and recycling contribute towards the circular economy, instead of incineration and landfills [93]. These authors highlighted the advantages of recycling and reuse towards economic circularity, due to the extension of a product's life cycle, and the disadvantages of traditional technologies such as landfills and incineration. These solid waste management techniques have their negative impacts on the environment, as have the liquid waste management technologies, such as sewage and chemical treatment. To avoid practices which are not compatible with the environment, other alternatives may be considered, such as the following: Detoxification; industry use; carbon sequestration; materials recovery [94]. Waste management may prove to be particularly 
problematic amongst the new European Union members [95]. The reality across the several European Union states is, in fact, extremely diverse [96].

\subsection{Innovation and Opportunities}

New technologies and innovative approaches are great opportunities to increase the sustainability of socioeconomic activities through a more circular economy [97], from a perspective of eco-innovation. In fact, the technological advances verified in the last few decades, such as autonomous robots, allow for the creation of new products and to redesign the productive processes. These evolutions may be great contributions in improving the circularity in socioeconomic activities, because they will help in the reduction of waste from raw materials. Circular economy is a broader concept that contains several dimensions [98]. However, there are also interesting opportunities in the development of new approaches and in the implementation of new ways of thinking about the several socioeconomic interrelationships [99], where recycling has its significance. The growing awareness of the several stakeholders about environmental problems and for the importance of a circular economy within current frameworks allow for these changes of socioeconomic paradigms. Considering the importance of the stakeholders' involvement and compliance with innovative strategies, these new ways of thinking are determinant for an effective eco-innovation implementation. For example, a deeper understanding of the several interconnections between energy, water, and food may bring additional insights [100], or new feed alternatives [101]. The applied scientific research brings about new opportunities to make the economic sectors more sustainable, namely those with more negative environmental impacts [102]. Research and innovation activities, as well as educational institutions, may bring forward relevant outcomes for the technological, governance, and social innovation that would provide an interesting support for the carbonization mitigation in cities [103]. Indeed, the research units and the institutions of higher education have a fundamental role to promote innovation and sustainable developments [104]. Reinforcing the network between business-higher education-research is an interesting pathway towards the circular economy [105]. The European Union promoted and created several initiatives, such as the Bio-based Industries Joint Undertaking, towards a more innovative and sustainable development in several member-states [106]. Sometimes changing old practices, with risks for sustainability, is not an easy task, which often requires adjusted approaches [107]. Some innovations in the commercialization chains, such as the agro-food short circuits, may promote a more circular economy in rural areas and improve the short profit margins of the farmers (for instance) [108]. In general, there is still a great need for significant steps to be taken in order to achieve the intended levels of sustainability [109], namely in waste management [110]. The 2030 Agenda for Sustainable Development, from the United Nations, and the European Union Action Plan for the Circular Economy, from the European Commission, are examples of these global concerns about sustainability [111], referred to in literature by several authors [112]. Recycling and innovation seem to be two determinant key words for a more circular economy [113].

\subsection{Economic Sectors}

The heterogeneity of the economic sectors across the European Union countries implies an existence of great heterogeneity in existing and applied circular economy strategies [114], including that for Electrical Waste and Electronic Equipment [115]. The industrial ecology (industrial networking to exchange resources and materials) and the related eco-industrial parks are adjusted approaches for a more sustainable planning [116], with interesting returns in some contexts [117], as shows an example from a Swedish region [118]. Nonetheless the exchange of data between industries may be a barrier for an effective industrial symbiosis [119]. Circular economy approaches may promote positive externalities [120] and economic growth [121]. The reverse is also true, where the economic and financial stabilities may create conditions for a more sustainable development [122]. These positive impacts are, for example, particularly relevant in agriculture, where the reuse of agro-waste [123] or waste from other sectors and activities [124] may improve the narrow margins of profit of the sector 
and bring alternatives for waste management [125]. Agricultural fertilizers appear to be an interesting alternative for several natural and anthropogenic wastes [126], having several applications [127] around the world [128], as well as the production of feed supplements [129] or in the construction industry [130], including end-of-life vehicle waste [131]. Circular economy activities in small and medium enterprises are interrelated and form a hierarchical structure where waste reduction is a priority [132], as well as product design [133].

\subsection{Bioeconomy}

The bioeconomy may contribute to a more sustainable and efficient development with positive externalities across several dimensions of society and the economy [134]. Buzzwords like bioeconomy, eco-innovation, or green economy, seem to have been replaced over recent years by the expression "circular economy" [135], which seems, in some circumstances (indeed), more comprehensive [136]. In any case, the concept of green (green houses or green buildings) seems to have its place [137], as well as the concept of bioeconomy [138] and green economy [1]. In some researches, the bioeconomy is viewed as a strategic approach for the European Union's development [139]. Other studies stress the need to interconnect these concepts in the debates about sustainability [140] and the importance of these approaches for the creation of new jobs, namely green [141], and economic growth [142]. Collaborative economy is another concept that appears in literature related with the circular economy [143], in amongst, for example, small and large companies [144], as well as the concept of ecodesign [145], where durability matters in the environmental tasks [146]. On the other hand, the circular economy has more than an economic and technological dimension, and should include social, behavioural [147], and cultural fields [148]. In fact, the behaviour and perceptions of the population about recycling, for instance, influence the effective implementation of circular economy strategies and plans [149]. The strategies adopted to promote the circular economy are different around the world. For example, China adopts more of a top-down strategy instead of the USA, European Union, and Japan [150]. In turn, China considers the circular economy as a response to the environmental problems from industrialization, and Europe has a perspective about this concept as an opportunity to make money and specifically to manage waste [151], focusing on innovation and business [152].

\section{Bibliometric Analysis with Bibliographic Data}

The bibliometric analysis allows us to highlight several pieces of interesting information available in the literature and may support an organized literature survey. For example, the studies developed by Martinho [6,7] produced relevant insights into the researches identified here. Following this, bibliometric dimensions related with the co-authorship, co-occurrence, citation, bibliographic coupling, and co-citation have been explored. Exploring these dimensions, in the above domains, contributes towards identifying gaps in the literature and to produce indicators which may support the several interested stakeholders, including the scientific researchers working on economic development compatible with the environmental and social dimensions, as referred by Mourao and Martinho [8]. The analysis performed in this section is based on the outputs obtained from the VOSviewer software through maps and tables.

\subsection{Co-Authorship}

Figure 1 shows three network visualization maps for the co-authorship related with the number of documents of an author, organization, and country. In this bibliometric field, the dimension of the respective circle represents the number of documents [153] and the proximity between circles presents the relatedness for the respective items (in this case the relatedness is about the number of co-authored documents). In addition to this, Table 1 provides complementary information. 


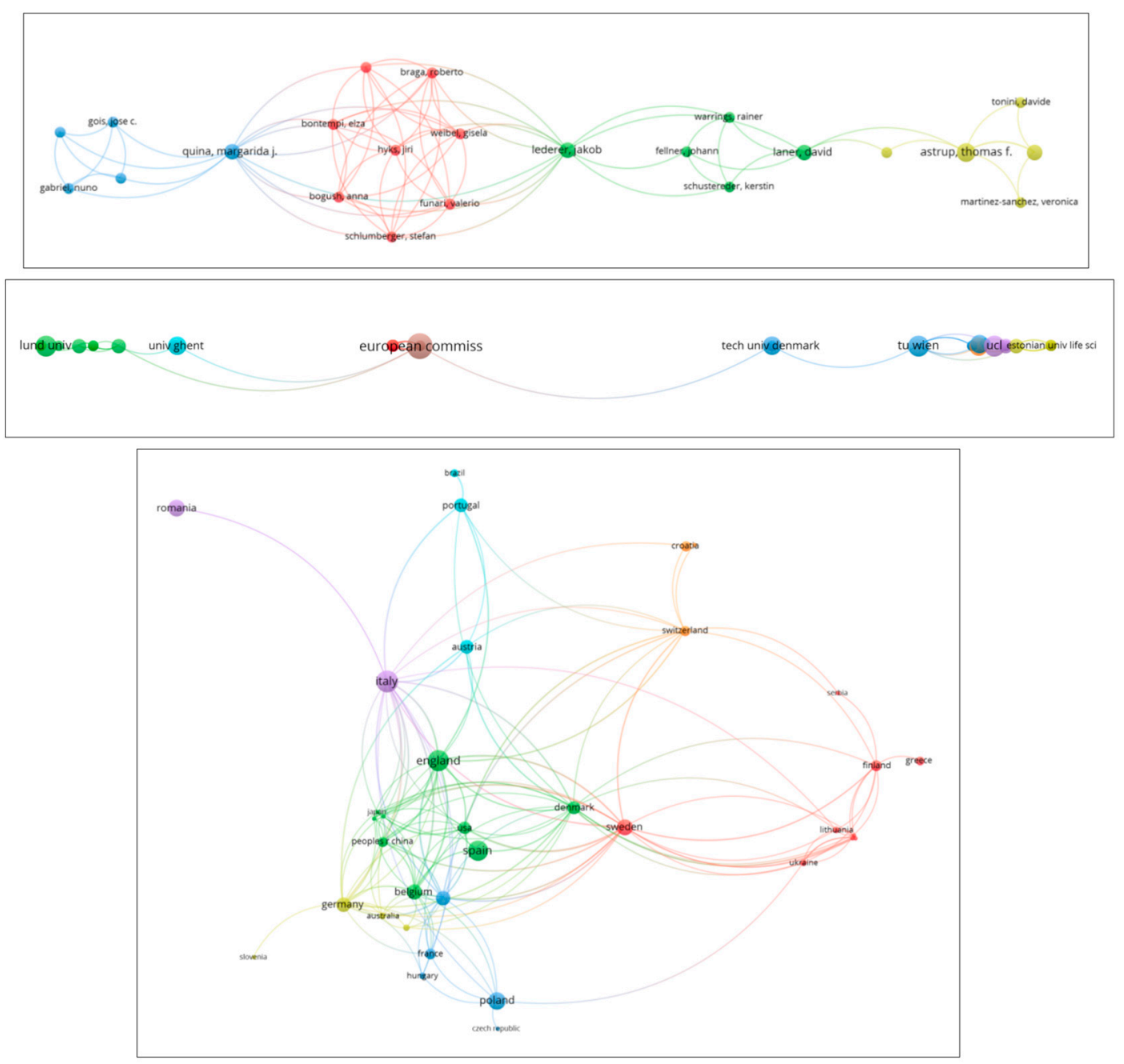

Figure 1. Co-authorship network visualization maps (1 as minimum number of documents of an author, of an organization and of a country)—the circle's dimension represents the number of documents.

In this way, the authors Astrup, Thomas F. and Faraca, Giorgia are those having more documents (the first with 3 documents and the second with 2 studies). Figure 1 also reveals a significant relatedness, because these authors' names are significantly close and belong to the same cluster. In general, the authors presented in Figure 1 and Table 1 published their work related with topics of circular economy and European Union in the average years 2018-2019 (before the search did not consider any year range). This shows that these fields have recently aroused the curiosity of the scientific community, noting that the "average publication year" is the average publication year of the documents published. It is also relevant to observe that there are many works related to the topic "circular economy", but not so much when the topic "European Union" is considered simultaneously.

The organization with more documents in these topics is the European Commission (with 6 documents), followed by the Lund Univ, Tu Wien, and UCL (all having 4 studies). For this item, the average year of publication begins in 2011, showing, again, a relatively new interest from the scientific community for these issues. The results presented in these figures and tables are only for the networked items. This explains some differences found, for example, in the average year of publication among the authors and the organizations. Finally, the documents published by Beijing Normal Univ, Dalarna Univ, Parthenope Univ Naples and Univ Bologna are the most cited, including on average. 
Table 1. Co-authorship statistics (1 as minimum number of documents of an author, of an organization and of a country).

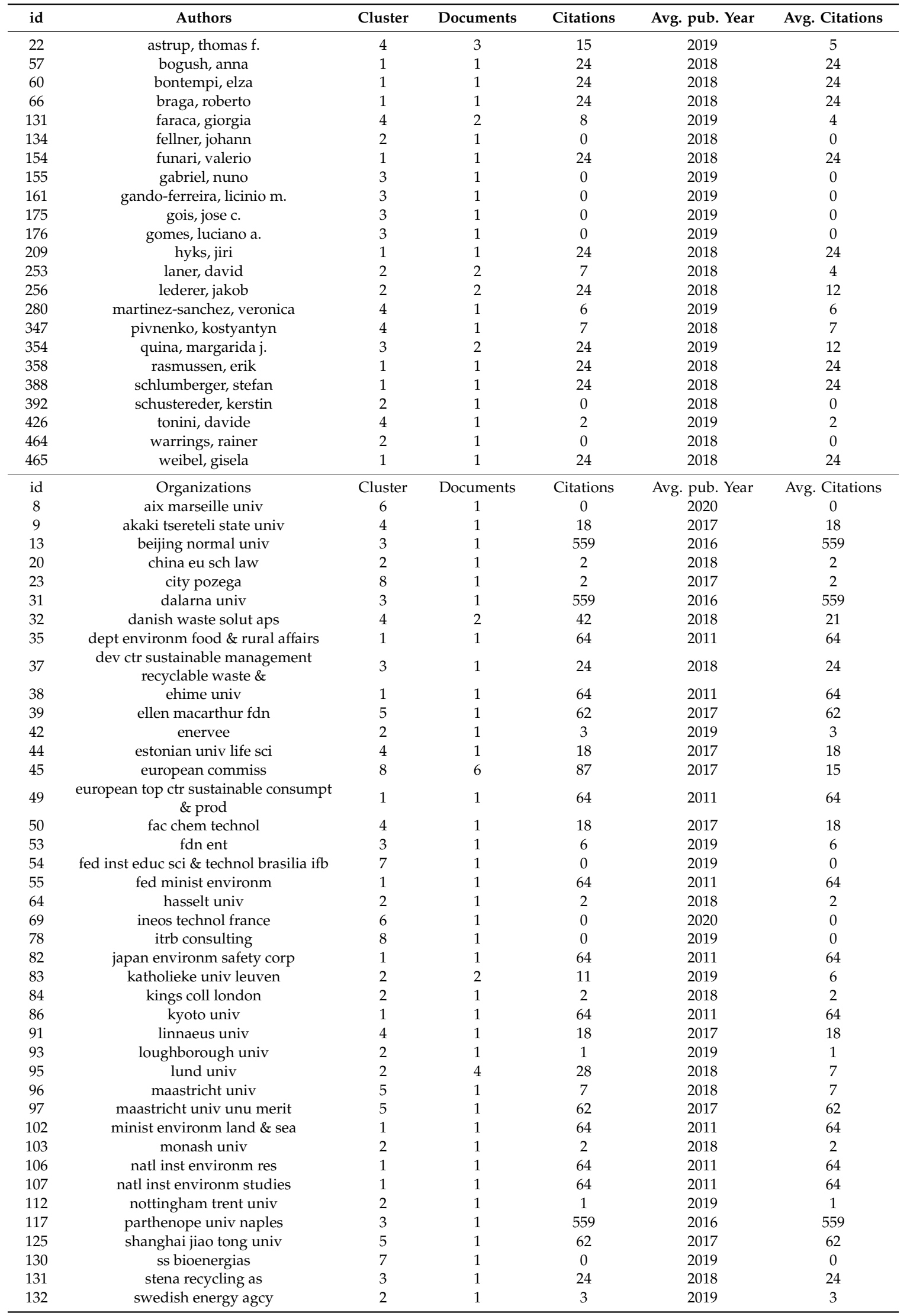


Table 1. Cont.

\begin{tabular}{|c|c|c|c|c|c|c|}
\hline id & Authors & Cluster & Documents & Citations & Avg. pub. Year & Avg. Citations \\
\hline 135 & taras shevchenko natl univ kyiv & 4 & 1 & 18 & 2017 & 18 \\
\hline 136 & tech univ denmark & 3 & 3 & 15 & 2019 & 5 \\
\hline 140 & towa technol & 1 & 1 & 64 & 2011 & 64 \\
\hline 142 & tu wien & 3 & 4 & 31 & 2018 & 8 \\
\hline 143 & $\mathrm{ucl}$ & 5 & 4 & 95 & 2018 & 24 \\
\hline 162 & univ cambridge & 6 & 1 & 0 & 2018 & 0 \\
\hline 163 & univ coimbra & 7 & 3 & 24 & 2019 & 8 \\
\hline 167 & univ eastern finland & 4 & 1 & 18 & 2017 & 18 \\
\hline 168 & univ estado santa catarina udesc oeste & 7 & 1 & 0 & 2019 & 0 \\
\hline 173 & univ ghent & 6 & 3 & 9 & 2019 & 3 \\
\hline 179 & univ latvia & 4 & 1 & 18 & 2017 & 18 \\
\hline 231 & vast & 1 & 1 & 64 & 2011 & 64 \\
\hline 236 & washington state dept ecol & 1 & 1 & 64 & 2011 & 64 \\
\hline id & Countries & Custer & Documents & Citations & Avg. pub. Year & Avg. Citations \\
\hline 1 & australia & 4 & 2 & 44 & 2018 & 22 \\
\hline 2 & austria & 6 & 9 & 228 & 2018 & 25 \\
\hline 3 & belgium & 2 & 11 & 99 & 2017 & 9 \\
\hline 4 & bolivia & 5 & 1 & 13 & 2019 & 13 \\
\hline 5 & brazil & 6 & 3 & 0 & 2019 & 0 \\
\hline 6 & croatia & 7 & 5 & 19 & 2017 & 4 \\
\hline 7 & czech republic & 3 & 1 & 0 & 2019 & 0 \\
\hline 8 & denmark & 2 & 8 & 163 & 2017 & 20 \\
\hline 16 & hungary & 3 & 2 & 1 & 2019 & 1 \\
\hline 18 & italy & 5 & 22 & 709 & 2018 & 32 \\
\hline 19 & japan & 2 & 1 & 64 & 2011 & 64 \\
\hline 20 & latvia & 1 & 1 & 18 & 2017 & 18 \\
\hline 21 & lithuania & 1 & 2 & 18 & 2018 & 9 \\
\hline 23 & netherlands & 3 & 10 & 189 & 2018 & 19 \\
\hline 24 & north ireland & 7 & 1 & 1 & 2018 & 1 \\
\hline 25 & norway & 4 & 2 & 56 & 2017 & 28 \\
\hline 26 & peoples $r$ china & 2 & 5 & 694 & 2016 & 139 \\
\hline 27 & poland & 3 & 15 & 188 & 2018 & 13 \\
\hline 28 & portugal & 6 & 9 & 30 & 1794 & 3 \\
\hline 29 & romania & 5 & 13 & 34 & 2018 & 3 \\
\hline 30 & serbia & 1 & 1 & 1 & 2019 & 1 \\
\hline 32 & slovenia & 4 & 1 & 2 & 2019 & 2 \\
\hline 33 & south korea & 2 & 1 & 64 & 2011 & 64 \\
\hline 34 & spain & 2 & 20 & 89 & 1917 & 4 \\
\hline 35 & sweden & 1 & 12 & 719 & 2017 & 60 \\
\hline 36 & switzerland & 7 & 5 & 39 & 2019 & 8 \\
\hline 38 & ukraine & 1 & 2 & 50 & 2017 & 25 \\
\hline 39 & usa & 2 & 7 & 114 & 2017 & 16 \\
\hline 40 & vietnam & 2 & 1 & 64 & 2011 & 64 \\
\hline
\end{tabular}

For the item country, Italy is the country with the highest number of documents (22), followed by England and Spain (with 21 and 20 studies, respectively). In addition, England and Spain have great relatedness, considering the proximity of the respective labels. Excluding residual exceptions, again in this item, it is observable that the average year of publication begins in 2011. Documents published by China have more average citations and are amongst those having more total citations.

It is important to stress here that, if for the authors and organizations there is not a great difference between the number of documents published by the leaders and the remaining items, for the item 
country these differences are more visible. This seems to show that there do not yet exist specialised teams of researchers and organizations/Universities in these fields, having an international network. However, there are countries that are publishing more about these subjects, such as Italy, Spain, and England, with great networking between England and Spain. Finally, the international impact is higher for the documents published by the Chinese community.

\subsection{Co-Occurrence}

Figure 2 and Table 2 present the results for the co-occurrence links. Table 2 only exhibits the items with more occurrences. In Figure 2, the dimension of the circles/labels represents the number of occurrences of the keywords and the proximity (relatedness) is connected with the number of documents where these keywords appear together.

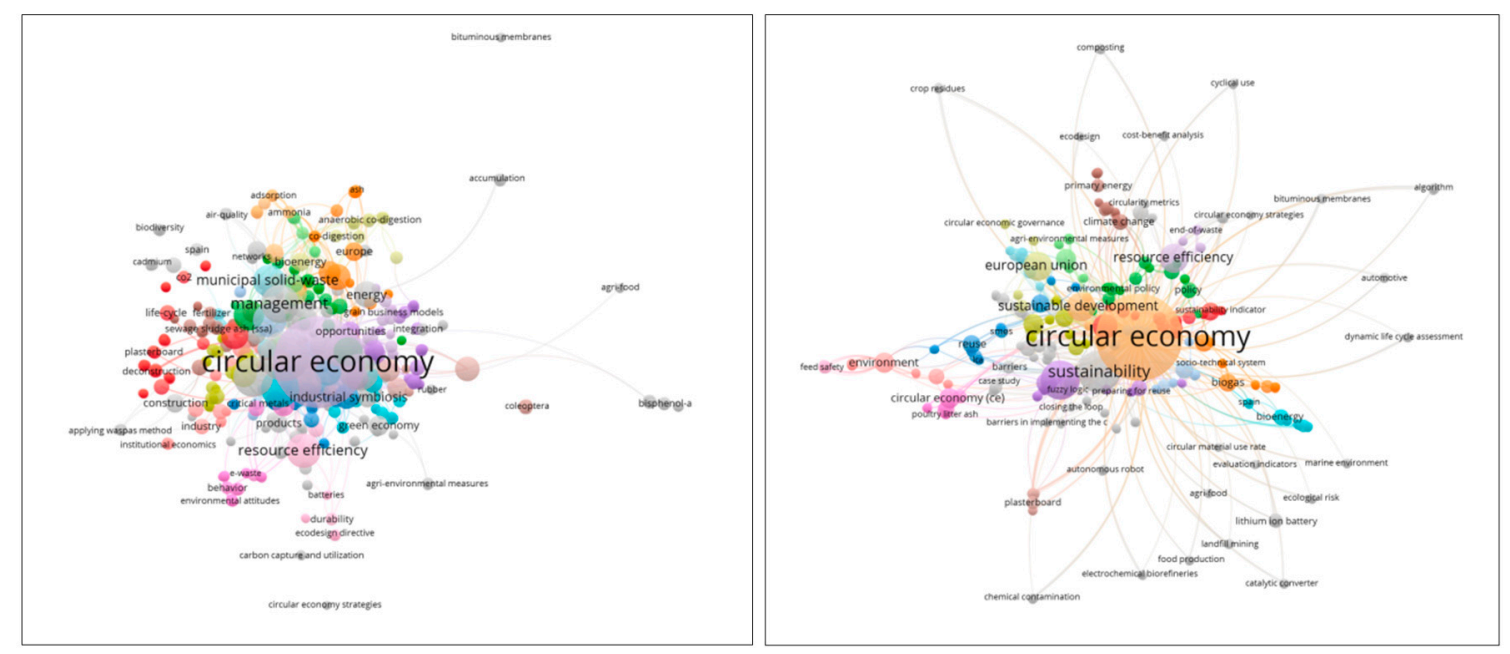

Figure 2. Co-occurrence network visualization maps (all keywords, 1 as minimum number of occurrences of a keyword; author keywords, 1 as minimum number of occurrences of a keyword) - the circle's dimension represents the number of occurrences.

Considering all keywords, the items with more occurrences, beyond circular economy, are 'sustainability, recycling, China, management, efficiency, and waste'. The average citations are greater in documents with the following keywords: Waste management, recycling, resource efficiency, and China.

Considering only the author keywords, the documents with more average citations are those where the following items appear: Reuse, resource efficiency, industrial ecology, recycling, and sustainability. This framework stresses the interest for the scientific community related with circular economy in the European Union, in aspects particularly related with sustainability, efficiency, ecology, recycling, and waste management. This shows that the concepts of management, efficiency, and recycling are the main focus, and that waste seems to be the main concern. However, the circular economy concept is broader, as is shown, amongst others, in the work of Alhola et al. [154]. 
Table 2. Co-occurrence statistics (all keywords, 1 as minimum number of occurrences of a keyword; author keywords, 1 as minimum number of occurrences of a keyword).

\begin{tabular}{|c|c|c|c|c|c|}
\hline id & All Keywords & Cluster & Occurrences & Avg. pub. Year & Avg. Citations \\
\hline 115 & circular economy & 14 & 97 & 1998 & 13 \\
\hline 825 & sustainability & 32 & 29 & 1949 & 27 \\
\hline 688 & recycling & 23 & 18 & 2017 & 47 \\
\hline 109 & china & 6 & 17 & 2018 & 40 \\
\hline 501 & management & 27 & 17 & 2019 & 5 \\
\hline 835 & sustainable development & 24 & 16 & 1892 & 6 \\
\hline 719 & resource efficiency & 18 & 14 & 2018 & 45 \\
\hline 686 & recovery & 12 & 13 & 2018 & 5 \\
\hline 555 & municipal solid-waste & 15 & 12 & 2019 & 6 \\
\hline 902 & waste & 2 & 11 & 2018 & 4 \\
\hline 912 & waste management & 23 & 11 & 2018 & 60 \\
\hline 306 & european union & 2 & 10 & 1816 & 15 \\
\hline 311 & european-union & 1 & 9 & 2018 & 2 \\
\hline 879 & transition & 31 & 9 & 2018 & 13 \\
\hline 60 & bioeconomy & 7 & 8 & 2018 & 7 \\
\hline 268 & energy & 22 & 8 & 2019 & 4 \\
\hline 434 & innovation & 14 & 8 & 1766 & 8 \\
\hline 479 & life-cycle assessment & 4 & 8 & 2018 & 12 \\
\hline 539 & model & 27 & 8 & 2019 & 2 \\
\hline 848 & system & 6 & 8 & 2019 & 15 \\
\hline 40 & barriers & 31 & 7 & 2019 & 9 \\
\hline 276 & environment & 17 & 7 & 2019 & 5 \\
\hline 432 & industrial symbiosis & 3 & 7 & 2018 & 3 \\
\hline 66 & biomass & 7 & 6 & 2018 & 4 \\
\hline 206 & design & 5 & 6 & 1682 & 4 \\
\hline 225 & eco-innovation & 17 & 6 & 2019 & 14 \\
\hline 428 & indicators & 20 & 6 & 1346 & 5 \\
\hline 851 & systems & 9 & 6 & 2018 & 5 \\
\hline id & Author keywords & Cluster & Occurrences & Avg. pub. year & Avg. citations \\
\hline 66 & circular economy & 16 & 87 & 2018 & 14 \\
\hline 451 & sustainability & 20 & 21 & 1922 & 29 \\
\hline 372 & recycling & 5 & 18 & 2017 & 47 \\
\hline 172 & european union & 13 & 10 & 1816 & 15 \\
\hline 392 & resource efficiency & 14 & 10 & 2018 & 60 \\
\hline 461 & sustainable development & 16 & 10 & 1816 & 5 \\
\hline 35 & bioeconomy & 1 & 7 & 2018 & 7 \\
\hline 67 & circular economy (ce) & 9 & 5 & 1614 & 23 \\
\hline 147 & environment & 10 & 5 & 2019 & 5 \\
\hline 209 & green economy & 11 & 5 & 2018 & 2 \\
\hline 230 & industrial ecology & 4 & 5 & 2017 & 58 \\
\hline 500 & waste management & 5 & 5 & 2017 & 16 \\
\hline 39 & biogas & 7 & 4 & 2018 & 5 \\
\hline 118 & eco-innovation & 1 & 4 & 2019 & 10 \\
\hline 232 & industrial symbiosis & 3 & 4 & 2019 & 1 \\
\hline 255 & life cycle assessment & 12 & 4 & 2019 & 3 \\
\hline 293 & municipal solid waste & 4 & 4 & 2018 & 17 \\
\hline 401 & reuse & 3 & 4 & 2018 & 141 \\
\hline 478 & transition & 7 & 4 & 2018 & 14 \\
\hline 36 & bioenergy & 6 & 3 & 2019 & 13 \\
\hline 77 & climate change & 8 & 3 & 2017 & 5 \\
\hline 228 & indicators & 10 & 3 & 1346 & 3 \\
\hline 258 & life cycle thinking & 44 & 3 & 2018 & 4 \\
\hline 334 & policy & 2 & 3 & 2018 & 4 \\
\hline 370 & recovery & 4 & 3 & 2018 & 9 \\
\hline 407 & secondary raw materials & 22 & 3 & 2018 & 4 \\
\hline 490 & waste & 2 & 3 & 2019 & 1 \\
\hline 507 & waste-to-energy & 5 & 3 & 2019 & 2 \\
\hline
\end{tabular}




\subsection{Citation}

For the filter related to citations, Figure 3 and Table 3 (for the items with more documents) exhibit the outputs obtained with the VOSviewer. In this case, the dimension of circles/labels represents the number of citations for the first map and the number of documents for the remaining maps. The proximity indicates the number of times they cite each other.
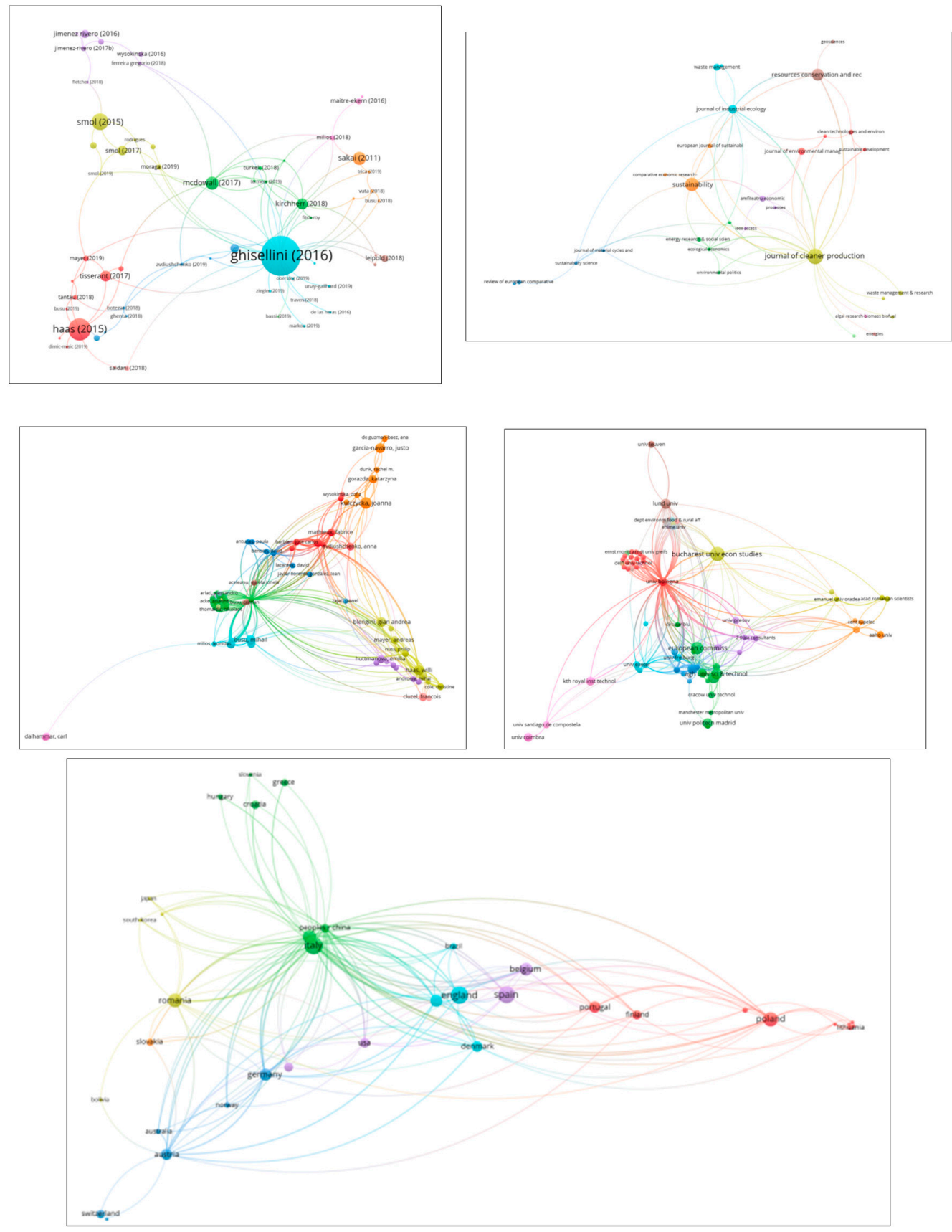

Figure 3. Citation network visualization maps ( 0 as minimum number of citations of a document (circle's dimension represents the number of citations), 1 as minimum number of documents of a source (circle's dimension represents the number of documents), 1 as minimum number of documents of an author (circle's dimension represents the number of documents), 1 as minimum number of documents of an organization (circle's dimension represents the number of documents), 1 as minimum number of documents of a country (circle's dimension represents the number of documents). 
Table 3. Citation statistics ( 1 as minimum number of documents of a source, 1 as minimum number of documents of an author, 1 as minimum number of documents of an organization, 1 as minimum number of documents of a country).

\begin{tabular}{|c|c|c|c|c|c|c|}
\hline id & Sources & Cluster & Documents & Citations & Avg. pub. Year & Avg. Citations \\
\hline 36 & journal of cleaner production & 4 & 20 & 746 & 2018 & 37 \\
\hline 63 & sustainability & 7 & 15 & 26 & 2019 & 2 \\
\hline 55 & resources conservation and recycling & 8 & 12 & 101 & 2018 & 8 \\
\hline 41 & journal of industrial ecology & 6 & 6 & 297 & 2017 & 50 \\
\hline 39 & journal of environmental management & 1 & 4 & 42 & 2018 & 11 \\
\hline 69 & waste management & 6 & 4 & 8 & 2018 & 2 \\
\hline 4 & amfiteatru economic & 5 & 3 & 6 & 2018 & 2 \\
\hline 13 & clean technologies and environmental policy & 1 & 2 & 34 & 2018 & 17 \\
\hline 20 & energy research \& social science & 2 & 2 & 34 & 2017 & 17 \\
\hline 28 & european journal of sustainable development & 7 & 2 & 0 & 2019 & 0 \\
\hline 58 & $\begin{array}{c}\text { review of european comparative \& international } \\
\text { environmental law }\end{array}$ & 3 & 2 & 16 & 2017 & 8 \\
\hline 70 & waste management \& research & 4 & 2 & 0 & 2019 & 0 \\
\hline 3 & algal research-biomass biofuels and bioproducts & 9 & 1 & 0 & 2019 & 0 \\
\hline 14 & $\begin{array}{c}\text { comparative economic research-central and } \\
\text { eastern europe }\end{array}$ & 7 & 1 & 9 & 2016 & 9 \\
\hline 17 & ecological economics & 2 & 1 & 46 & 2018 & 46 \\
\hline 18 & energies & 10 & 1 & 1 & 2019 & 1 \\
\hline 19 & energy efficiency & 3 & 1 & 3 & 2019 & 3 \\
\hline 23 & environmental politics & 2 & 1 & 0 & & 0 \\
\hline 29 & fme transactions & 6 & 1 & 1 & 2019 & 1 \\
\hline 31 & geosciences & 8 & 1 & 0 & 2019 & 0 \\
\hline 33 & ieee access & 5 & 1 & 0 & 2019 & 0 \\
\hline 42 & journal of material cycles and waste management & 3 & 1 & 64 & 2011 & 64 \\
\hline 51 & processes & 5 & 1 & 3 & 2018 & 3 \\
\hline 53 & rege-revista de gestao & 2 & 1 & 0 & 2019 & 0 \\
\hline 56 & resources policy & 1 & 1 & 0 & 2019 & 0 \\
\hline 59 & revista de derecho comunitario europeo & 11 & 1 & 1 & 2016 & 1 \\
\hline 64 & sustainability science & 3 & 1 & 10 & 2018 & 10 \\
\hline 65 & sustainable development & 1 & 1 & 0 & & 0 \\
\hline 67 & urban planning & 4 & 1 & 1 & 2019 & 1 \\
\hline 71 & $\begin{array}{l}\text { water alternatives-an interdisciplinary journal on } \\
\text { water politics and development }\end{array}$ & 4 & 1 & 0 & 2019 & 0 \\
\hline id & Authors & Cluster & Documents & Citations & Avg. pub. Year & Avg. Citations \\
\hline 248 & kulczycka, joanna & 7 & 4 & 146 & 2017 & 37 \\
\hline 404 & smol, marzena & 7 & 4 & 146 & 2017 & 37 \\
\hline 55 & blengini, gian andrea & 4 & 3 & 22 & 2018 & 7 \\
\hline 76 & busu, mihail & 6 & 3 & 3 & 2019 & 1 \\
\hline 165 & garcia-navarro, justo & 7 & 3 & 23 & 2017 & 8 \\
\hline 185 & haas, willi & 4 & 3 & 192 & 2017 & 64 \\
\hline 219 & jimenez-rivero, ana & 7 & 3 & 23 & 2017 & 8 \\
\hline 467 & wiedenhofer, dominik & 4 & 3 & 192 & 2017 & 64 \\
\hline 23 & avdiushchenko, anna & 1 & 2 & 34 & 2018 & 17 \\
\hline 54 & bleischwitz, raimund & 1 & 2 & 69 & 2018 & 35 \\
\hline 90 & cluzel, francois & 10 & 2 & 10 & 2019 & 5 \\
\hline 101 & dalhammar, carl & 9 & 2 & 17 & 2018 & 9 \\
\hline 178 & gorazda, katarzyna & 7 & 2 & 104 & 2017 & 52 \\
\hline 203 & huang, beijia & 1 & 2 & 69 & 2018 & 35 \\
\hline 206 & huttmanova, emilia & 5 & 2 & 0 & 2019 & 0 \\
\hline 228 & kemp, rene & 1 & 2 & 69 & 2018 & 35 \\
\hline 241 & krausmann, fridolin & 4 & 2 & 183 & 2017 & 92 \\
\hline 259 & leroy, yann & 10 & 2 & 10 & 2019 & 5 \\
\hline 284 & mathieux, fabrice & 1 & 2 & 19 & 2018 & 10 \\
\hline 285 & mayer, andreas & 4 & 2 & 21 & 2019 & 11 \\
\hline 286 & mcdowall, will & 1 & 2 & 69 & 2018 & 35 \\
\hline 378 & saidani, michael & 10 & 2 & 10 & 2019 & 5 \\
\hline 431 & trica, carmen lenuta & 6 & 2 & 0 & 2019 & 0 \\
\hline 435 & turkeli, serdar & 1 & 2 & 69 & 2018 & 35 \\
\hline 441 & valentiny, tomas & 5 & 2 & 0 & 2019 & 0 \\
\hline 476 & wzorek, zbigniew & 7 & 2 & 104 & 2017 & 52 \\
\hline 478 & yannou, bernard & 10 & 2 & 10 & 2019 & 5 \\
\hline id & Organizations & Cluster & Documents & Citations & Avg. pub. Year & Avg. Citations \\
\hline 16 & bucharest univ econ studies & 4 & 8 & 16 & 2019 & 2 \\
\hline 45 & european commiss & 2 & 6 & 87 & 2017 & 15 \\
\hline 5 & agh univ sci \& technol & 2 & 5 & 148 & 2017 & 30 \\
\hline 119 & polish acad sci & 2 & 5 & 147 & 2017 & 29 \\
\hline 95 & lund univ & 8 & 4 & 28 & 2018 & 7 \\
\hline 143 & $\mathrm{ucl}$ & 3 & 4 & 95 & 2018 & 24 \\
\hline 204 & univ politecn madrid & 2 & 4 & 48 & 2017 & 12 \\
\hline
\end{tabular}


Table 3. Cont.

\begin{tabular}{|c|c|c|c|c|c|c|}
\hline id & Sources & Cluster & Documents & Citations & Avg. pub. Year & Avg. Citations \\
\hline 85 & kth royal inst technol & 9 & 3 & 37 & 2018 & 12 \\
\hline 157 & univ bologna & 1 & 3 & 584 & 2018 & 195 \\
\hline 163 & univ coimbra & 9 & 3 & 24 & 2019 & 8 \\
\hline 173 & univ ghent & 2 & 3 & 9 & 2019 & 3 \\
\hline 2 & aalborg univ & 5 & 2 & 42 & 2019 & 21 \\
\hline 3 & aalto univ & 7 & 2 & 7 & 2018 & 4 \\
\hline 10 & alpen adria univ & 7 & 2 & 180 & 2017 & 90 \\
\hline 29 & cracow univ technol & 2 & 2 & 104 & 2017 & 52 \\
\hline 81 & jagiellonian univ & 2 & 2 & 34 & 2018 & 17 \\
\hline 83 & katholieke univ leuven & 2 & 2 & 11 & 2019 & 6 \\
\hline 169 & univ exeter & 6 & 2 & 4 & 1009 & 2 \\
\hline 171 & univ freiburg & 6 & 2 & 60 & 2018 & 30 \\
\hline 181 & univ leuven & 8 & 2 & 16 & 2017 & 8 \\
\hline 184 & univ lodz & 3 & 2 & 10 & 2018 & 5 \\
\hline 207 & univ presov & 5 & 2 & 0 & 2019 & 0 \\
\hline 212 & univ santiago de compostela & 9 & 2 & 8 & 2018 & 4 \\
\hline 214 & univ shanghai sci \& technol & 3 & 2 & 69 & 2018 & 35 \\
\hline id & Countries & Cluster & Documents & Citations & Avg. pub. Year & Avg. Citations \\
\hline 18 & italy & 2 & 22 & 709 & 2018 & 32 \\
\hline 9 & england & 6 & 21 & 199 & 1922 & 9 \\
\hline 34 & spain & 5 & 20 & 89 & 1917 & 4 \\
\hline 27 & poland & 1 & 15 & 188 & 2018 & 13 \\
\hline 29 & romania & 4 & 13 & 34 & 2018 & 3 \\
\hline 35 & sweden & 2 & 12 & 719 & 2017 & 60 \\
\hline 3 & belgium & 5 & 11 & 99 & 2017 & 9 \\
\hline 14 & germany & 3 & 10 & 156 & 2018 & 16 \\
\hline 23 & netherlands & 6 & 10 & 189 & 2018 & 19 \\
\hline 2 & austria & 3 & 9 & 228 & 2018 & 25 \\
\hline 28 & portugal & 1 & 9 & 30 & 1794 & 3 \\
\hline 8 & denmark & 6 & 8 & 163 & 2017 & 20 \\
\hline 39 & usa & 5 & 7 & 114 & 2017 & 16 \\
\hline 11 & finland & 1 & 6 & 55 & 2018 & 9 \\
\hline 12 & france & 5 & 6 & 26 & 2019 & 4 \\
\hline 6 & croatia & 2 & 5 & 19 & 2017 & 4 \\
\hline 26 & peoples $r$ china & 2 & 5 & 694 & 2016 & 139 \\
\hline 36 & switzerland & 3 & 5 & 39 & 2019 & 8 \\
\hline 15 & greece & 2 & 4 & 12 & 2019 & 3 \\
\hline 31 & slovakia & 7 & 4 & 0 & 2019 & 0 \\
\hline 5 & brazil & 6 & 3 & 0 & 2019 & 0 \\
\hline 1 & australia & 3 & 2 & 44 & 2018 & 22 \\
\hline 16 & hungary & 2 & 2 & 1 & 2019 & 1 \\
\hline 21 & lithuania & 1 & 2 & 18 & 2018 & 9 \\
\hline 25 & norway & 3 & 2 & 56 & 2017 & 28 \\
\hline 38 & ukraine & 1 & 2 & 50 & 2017 & 25 \\
\hline 4 & bolivia & 4 & 1 & 13 & 2019 & 13 \\
\hline 7 & czech republic & 1 & 1 & 0 & 2019 & 0 \\
\hline 10 & estonia & 1 & 1 & 18 & 2017 & 18 \\
\hline 13 & georgia & 1 & 1 & 18 & 2017 & 18 \\
\hline 19 & japan & 4 & 1 & 64 & 2011 & 64 \\
\hline 20 & latvia & 1 & 1 & 18 & 2017 & 18 \\
\hline 30 & serbia & 3 & 1 & 1 & 2019 & 1 \\
\hline 32 & slovenia & 2 & 1 & 2 & 2019 & 2 \\
\hline 33 & south korea & 4 & 1 & 64 & 2011 & 64 \\
\hline 40 & vietnam & 4 & 1 & 64 & 2011 & 64 \\
\hline
\end{tabular}

The sources with most documents, in Table 3, are the following: Journal of Cleaner Production (20), Sustainability (15), and Resources Conservation and Recycling (12). On the other hand, the Journal of Cleaner Production is that with more citations, and the Journal of Material Cycles and Waste Management is that which has more average citations. There is a significant difference between the number of documents published by these sources and those remaining. However, together these journals published 47 documents, showing that there is a particular concentration of the filtered documents in 3 journals.

The authors Joanna Kulczycka and Marzena Smol are those with more documents also showing a significant relatedness, having worked together on the same documents. The authors with more total citations are the following: Willi Haas; Dominik Wiedenhofer; and Fridolin Krausmann. These authors also belong to the same cluster. In general, the authors with more documents and citations in this link also have more relatedness, having also worked together, showing that, when there are specialised 
teams for these topics, in general, they are small and come from the same organization, or at least, from the same country.

The Bucharest Univ Econ Studies is that which has more documents (8), but Univ Bologna is where the published documents received more total and average citations. As stressed before, the more productive organizations are not the same with greater international impact.

\subsection{Bibliographic Coupling}

Figure 4 shows the output for the links in bibliographic coupling where the relatedness is based on the number of references they share. This figure highlights that the document "ghisellini (2016)" is the most cited. Considering sources/journals, there is a relevant relatedness between the Journal of Cleaner Production and the following publications: Business Strategy and the Environment; Energies; and Marketing and Management of Innovations. The same happens for the Sustainability journal and the following publications: New Biotechnology; Autex Research Journal; or Journal of Food and Nutrition Research. However, there is a significant difference between the leading publication in these two clusters and other journals for several indicators (number of documents and citations). On the other hand, the Journal of Cleaner Production shares references with journals from the business, environment, energies, marketing, and innovation areas, and the Sustainability journal shares references with sources from the biotechnology, food, and nutrition issues. This reveals the relationships, for these topics, between sustainability and business aspects, namely those related with innovation. It also shows the interlinkages between sustainable development and new biotechnological approaches.

The organization that has more documents (Bucharest Univ Econ Studies) also shares publications containing references with a relevant number of organizations around the world. However, the organization with more citations (Univ Bologna) shares references with a more limited number of organizations. Finally, Australia and Norway are clustered together (this means that the authors from these countries usually share references). Brazil, England, Austria, and Portugal are grouped in another cluster, and Croatia, Serbia, Switzerland, and Northern Ireland compose another cluster. Some countries from the Asian Continent and the USA form another group, and the remaining countries are clustered into two bigger groups. It seems that, in general, there are more references shared between authors from countries with some closer affinities. In any case, the fields related to circular economy in the European Union create curiosity amongst researchers around the world. 

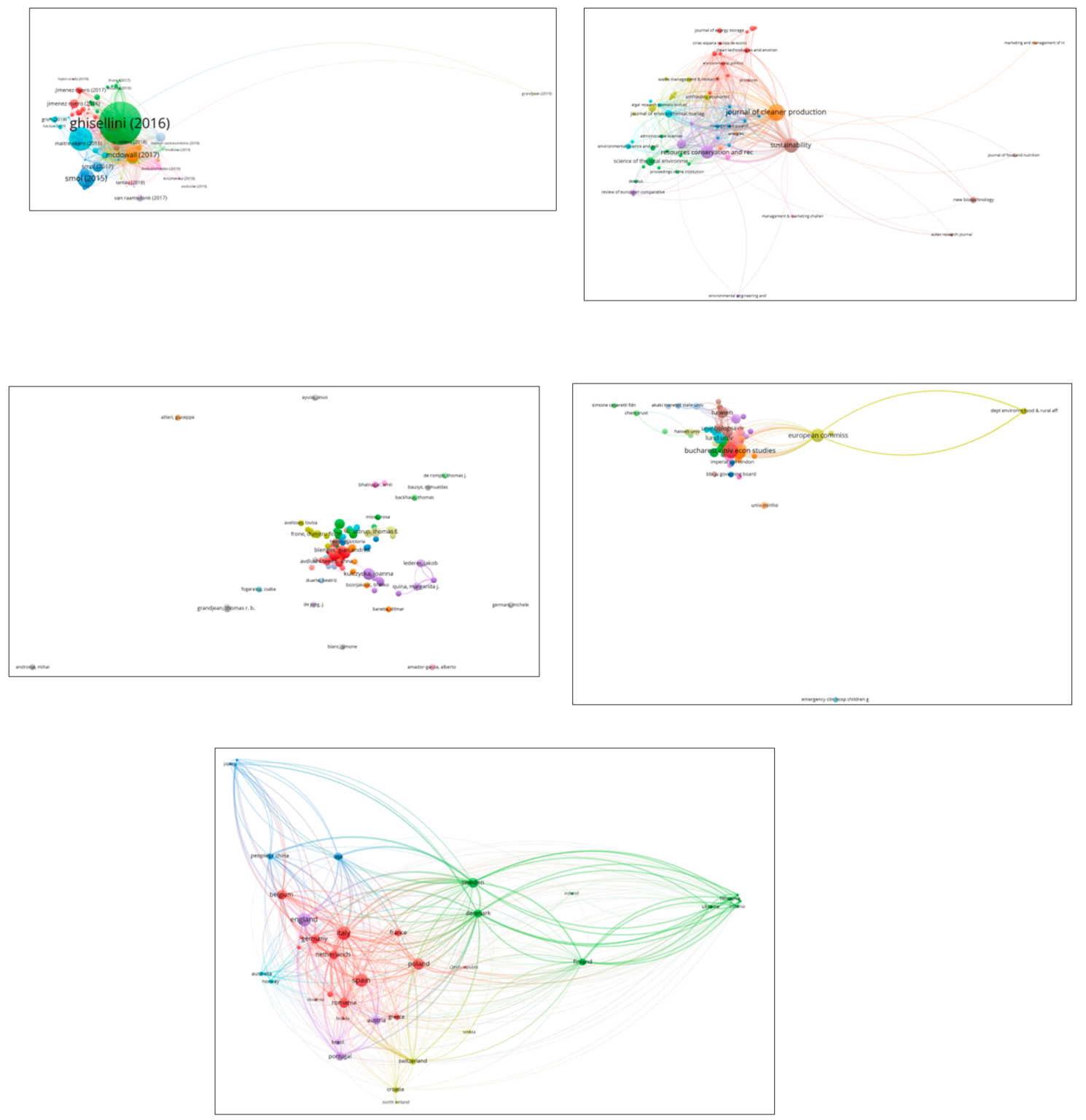

Figure 4. Bibliographic coupling network visualization maps ( 0 as minimum number of citations of a document (circle's dimension represents the number of citations), 1 as minimum number of documents of a source (circle's dimension represents the number of documents), 1 as minimum number of documents of an author (circle's dimension represents the number of documents), 1 as minimum number of documents of an organization (circle's dimension represents the number of documents), 1 as minimum number of documents of a country (circle's dimension represents the number of documents).

\subsection{Co-Citation}

In these filters the relatedness is based on the number of times the items are cited together (Figure 5). For instance, the Journal of Cleaner Production is co-cited with the following publications (amongst others): J Ind Ecol; Ecol Econ; Nature; Clean Technol Envir; Res Policy; Technol Forecast Soc. For the item author, the European Commission is co-cited with the following authors: OECD; Bleischwitz, R; Howlett, M; Wilts, H; Eco-Innovation, Observatory; Winans, K; Zavadskas, Ek; Ekvall, T. In general, the most co-cited sources are from the same fields, and the authors who are more cited together have some affinity (in this case three organizations appear, the European Commission, OECD, and the Eco-Innovation Observatory). 


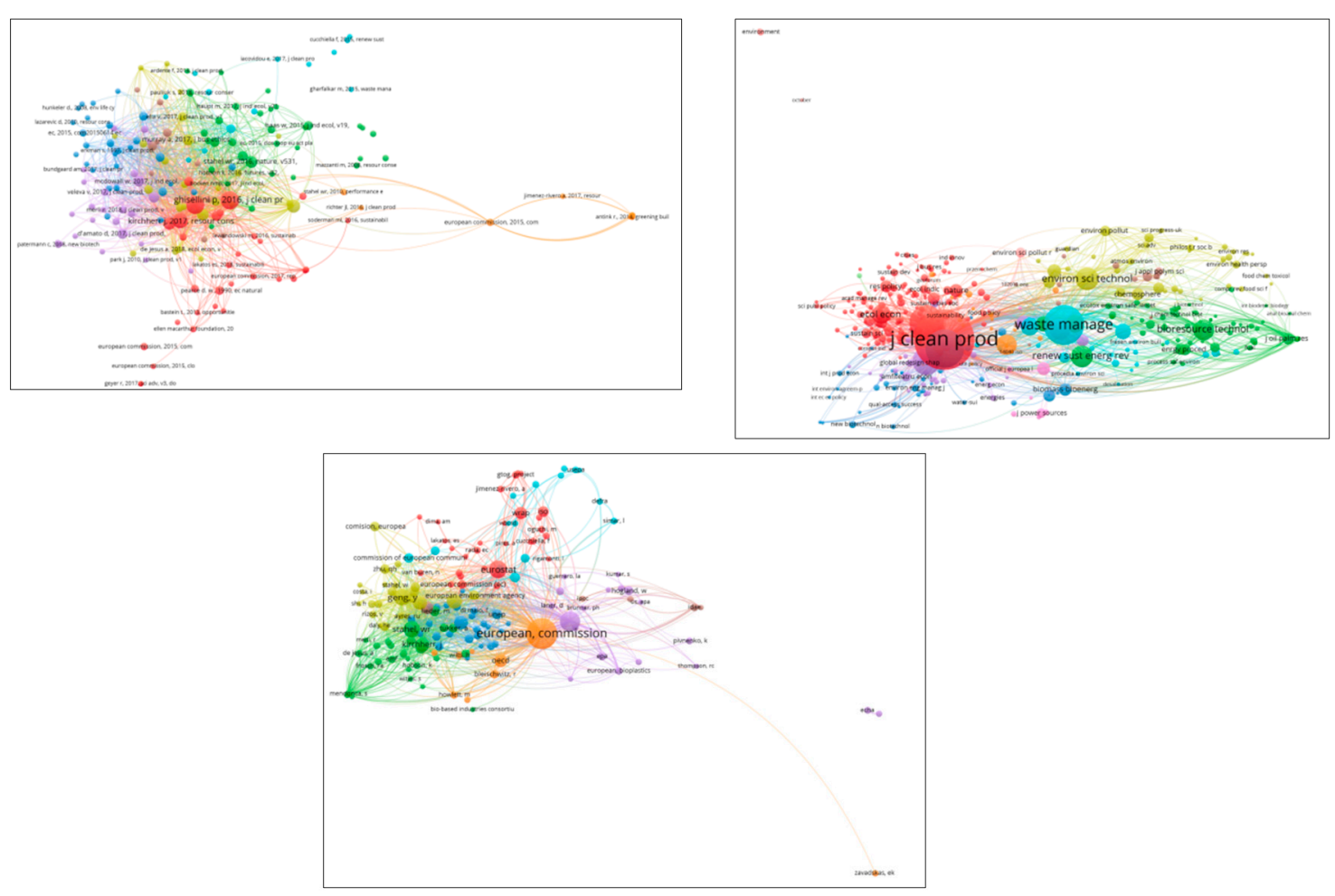

Figure 5. Co-citation network visualization maps ( 3 as minimum number of citations of a cited reference (circle's dimension represents the number of citations), 3 as minimum number of citations of a source (circles dimension represents the number of citations); 5 as minimum number of citations of an author (circle's dimension represents the number of citations).

\section{Discussion and Conclusions}

This research was aimed to perform a literature review, complemented by a bibliometric analysis, about the topics "circular economy" and "European Union". We referred to VOSviewer software for the bibliometric analysis and to the platform Web of Science (as the major source of our observed references). From this scientific platform, 144 studies were identified.

The bibliometric effort identified that several issues related to the circular economy have attracted the attention amongst researchers $[76,82,103,122]$. This identification has shown the relevance of studies performed in these fields and the enormous potential to be explored in future work. On the other hand, it is also worth highlighting the great number of documents produced by international institutions such as the European Commission, revealing institutional concerns about circularity in the European economy $[14,88,103]$. In addition, within these frameworks another question is raised about the international impact from scientific production and, in this dimension, the studies published by Chinese authors have had a greater impact in the scientific community. Keywords like sustainability, recycling, reuse, management, efficiency, waste, and industrial ecology stress the concerns with waste management.

The bibliometric analysis has also shown that the more productive authors are those with more relatedness, since, in general, they had worked together. However, it seems that there are some specialised teams in these fields, usually involving a small number of members and from the same institution, or, at least, from the same country. This framework shows that it is important to promote further networking and more specialised teams around the world for these domains. These are interesting insights, presenting that the organizations with more impact seem to be more focused on positive returns across the scientific community. Finally, the authors from Australia and Norway tend to share references more likely, as well as those from Brazil, England, Austria, and Portugal. 
In terms of practical implications, there is a great potential to be highlighted in the domains related with the circular economy in the European Union, because they are still emerging areas. In general, the authors who publish on these topics have undergone very little networking. In turn, the findings obtained stress that the scientific community, related with these topics, focused their research, namely, on waste recycling and on business interrelationships. There are some fields' gaps here that may be addressed by the literature in future research.

In future studies, there are some topics, related with circular economy dimensions, that could be further addressed, as, for instance, the following: The design of companies' supply chains [155]; the indices, indicators, and assessment approaches [156]; the technological dimensions supporting the circular economy [157]; the circularity assessment in companies [158]; the relationships regarding human presence in organizations [159]; and implementation suggestions for recycling [160].

Author Contributions: V.D.M.: Conceptualization, Methodology, Formal Analysis; P.R.M.: Methodology, Formal Analysis. All authors have read and agreed to the published version of the manuscript.

Funding: This work is funded by National Funds through the FCT_Foundation for Science and Technology, I.P., within the scope of the project Ref ${ }^{a}$ UIDB/00681/2020. Paulo Mourao acknowledges the following: This paper is financed by National Funds of the FCT-Portuguese Foundation for Science and Technology within the project «UIDB/03182/2020».

Acknowledgments: Furthermore we would like to thank the CERNAS Research Centre and the Polytechnic Institute of Viseu and NIPE (UMinho) for their support.

Conflicts of Interest: The authors declare no conflict of interest.

\section{References}

1. Gregorio, V.F.; Pié, L.; Terceño, A. A systematic literature review of bio, green and circular economy trends in publications in the field of economics and business management. Sustainability 2018, 10, 4232. [CrossRef]

2. Türkeli, S.; Kemp, R.; Huang, B.; Bleischwitz, R.; McDowall, W. Circular economy scientific knowledge in the European Union and China: A bibliometric, network and survey analysis (2006-2016). J. Clean. Prod. 2018, 197, 1244-1261. [CrossRef]

3. Web of Science Core Collection. Available online: https://apps.webofknowledge.com/WOS GeneralSearch_input.do?product=WOS\&search_mode=GeneralSearch\&SID=F2iElOePbBk5TSuv2Oa\& preferencesSaved $=$ (accessed on 13 December 2019).

4. VOSviewer-Visualizing Scientific Landscapes. Available online: https://www.vosviewer.com// (accessed on 16 December 2019).

5. Web of Science All Databases. Available online: https://apps.webofknowledge.com/UA_GeneralSearch_input. do?product=UA\&SID=F6gFOEpH43wjJrd3rDG\&search_mode=GeneralSearch (accessed on 13 December 2019).

6. Martinho, V.D. Interrelationships between renewable energy and agricultural economics: An overview. Energy Strategy Rev. 2018, 22, 396-409. [CrossRef]

7. Martinho, V.D. Best management practices from agricultural economics: Mitigating air, soil and water pollution. Sci. Total Environ. 2019, 688, 346-360. [CrossRef]

8. Mourão, P.; Martinho, V.D. Forest entrepreneurship: A bibliometric analysis and a discussion about the co-authorship networks of an emerging scientific field. J. Clean. Prod. 2020, 256, 120413. [CrossRef]

9. Takey, S.M.; Carvalho, M. Fuzzy front end of systemic innovations: A conceptual framework based on a systematic literature review. Technol. Forecast. Soc. Chang. 2016, 111, 97-109. [CrossRef]

10. Xu, S.; Zhang, X.; Feng, L.; Yang, W. Disruption risks in supply chain management: A literature review based on bibliometric analysis. Int. J. Prod. Res. 2020, 58, 3508-3526. [CrossRef]

11. Wysokińska, Z. The "New" Environmental Policy Of The European Union: A Path To Development Of A Circular Economy And Mitigation Of The Negative Effects Of Climate Change. Comp. Econ. Res. 2016, 19, 57-73. [CrossRef]

12. Blengini, G.A.; Garbarino, E.; Bevilacqua, P. Sustainability and integration between mineral resources and c\&dw management: Overview of key issues towards a resource-efficient Europe. Environ. Eng. Manag. J. 2017, 16, 493-502. [CrossRef] 
13. Botezat, E.A.; Dodescu, A.O.; Văduva, S.; Fotea, S.L. An exploration of circular economy practices and performance among romanian producers. Sustainability 2018, 10, 3191. [CrossRef]

14. Ghenta, M.; Matei, A. National Scientific Research Institute for Labour and Social Protection (INCSMPS). SMEs and the circular economy: From policy to difficulties encountered during implementation. Amfiteatru Econ. 2018, 20, 294-309. [CrossRef]

15. Burlakovs, J.; Kriipsalu, M.; Klavins, M.; Bhatnagar, A.; Vincevica-Gaile, Z.; Stenis, J.; Jani, Y.; Mykhaylenko, V.; Denafas, G.; Turkadze, T.; et al. Paradigms on landfill mining: From dump site scavenging to ecosystem services revitalization. Resour. Conserv. Recycl. 2017, 123, 73-84. [CrossRef]

16. Flachenecker, F. The causal impact of material productivity on macroeconomic competitiveness in the European Union. Environ. Econ. Policy Stud. 2017, 20, 17-46. [CrossRef]

17. Frone, D.F.; Frone, S. Resource Efficiency Objectives and Issues for a Green Economy. Sci. Pap. Ser. Manag. Econ. Eng. Agric. Rural Dev. 2015, 15, 133-138.

18. Huttmanová, E.; Novotný, R.; Valentiny, T. An Analytical View to Environmental Quality of Life in the European Union Countries. Eur. J. Sustain. Dev. 2019, 8, 409. [CrossRef]

19. Kushairi, A.; Loh, S.K.; Azman, I.; Hishamuddin, E.; Ong-Abdullah, M.; Izuddin, Z.B.M.N.; Razmah, G.; Sundram, S.; Parveez, G.K.A. Oil palm economic performance in malaysia and R\&D progress in 2017. J. Oil Palm Res. 2018, 30, 163-195. [CrossRef]

20. Huttmanová, E.; Valentiny, T. Assessment of the economic pillar and environmental pillar of sustainable development in the European Union. Eur. J. Sustain. Dev. 2019, 8, 289. [CrossRef]

21. Jiménez-Rivero, A.; De Guzmán-Báez, A.; Navarro, J.G. Enhanced on-site waste management of plasterboard in construction works: A case study in Spain. Sustainability 2017, 9, 450. [CrossRef]

22. Lazarevic, D.; Valve, H. Narrating expectations for the circular economy: Towards a common and contested European transition. Energy Res. Soc. Sci. 2017, 31, 60-69. [CrossRef]

23. Lisjak, J.; Schade, S.; Kotsev, A. closing data gaps with citizen science? Findings from the Danube region. ISPRS Int. J. Geo-Inf. 2017, 6, 277. [CrossRef]

24. Shemfe, M.B.; Gadkari, S.; Sadhukhan, J. Social hotspot analysis and trade policy implications of the use of bioelectrochemical systems for resource recovery from wastewater. Sustainability 2018, 10, 3193. [CrossRef]

25. Muradin, M.; Joachimiak-Lechman, K.; Foltynowicz, Z. Evaluation of eco-efficiency of two alternative agricultural biogas plants. Appl. Sci. 2018, 8, 2083. [CrossRef]

26. Ammenberg, J.; Anderberg, S.; Lönnqvist, T.; Grönkvist, S.; Sandberg, T. Biogas in the transport sector-actor and policy analysis focusing on the demand side in the Stockholm region. Resour. Conserv. Recycl. 2018, 129, 70-80. [CrossRef]

27. Buşu, C.; Busu, M. Modeling the circular economy processes at the EU level using an evaluation algorithm Based on Shannon entropy. Processes 2018, 6, 225. [CrossRef]

28. Avdiushchenko, A.; Zając, P. Circular economy indicators as a supporting tool for european regional development policies. Sustainability 2019, 11, 3025. [CrossRef]

29. Kristensen, H.S.; Mosgaard, M.A. A review of micro level indicators for a circular economy-Moving away from the three dimensions of sustainability? J. Clean. Prod. 2020, 243, 118531. [CrossRef]

30. Smol, M.; Kulczycka, J.; Avdiushchenko, A. Circular economy indicators in relation to eco-innovation in European regions. Clean Technol. Environ. Policy 2017, 19, 669-678. [CrossRef]

31. Tantau, A.D.; Maassen, M.A.; Fratila, L. Models for analyzing the dependencies between indicators for a circular economy in the European Union. Sustainability 2018, 10, 2141. [CrossRef]

32. Bahn-Walkowiak, B.; Wilts, $\mathrm{H}$. The institutional dimension of resource efficiency in a multi-level governance system-Implications for policy mix design. Energy Res. Soc. Sci. 2017, 33, 163-172. [CrossRef]

33. Castillo, A.C.; Angelis-Dimakis, A. Analysis and recommendations for European carbon dioxide utilization policies. J. Environ. Manag. 2019, 247, 439-448. [CrossRef]

34. Fitch-Roy, O.; Benson, D.; Monciardini, D. Going around in circles? Conceptual recycling, patching and policy layering in the EU circular economy package. Environ. Politics 2019, 29, 983-1003. [CrossRef]

35. Heras, B.P.D.L. La gestión eficiente de recursos en la Unión Europea: Alcance e impacto de la normativa europea para una economía más sostenible y circular. Rev. De Derecho Comunitario Eur. 2016, 781-817. [CrossRef]

36. Chelinho, S.; Pereira, C.; Breitenbach, P.; Baretta, D.; Sousa, J.P. Quality standards for urban waste composts: The need for biological effect data. Sci. Total Environ. 2019, 694, 133602. [CrossRef] [PubMed] 
37. De Römph, T.J.; Van Calster, G. REACH in a circular economy: The obstacles for plastics recyclers and regulators. Rev. Eur. Comp. Int. Environ. Law 2018, 27, 267-277. [CrossRef]

38. Fletcher, C.A.; Hooper, P.D.; Dunk, R.M. Unintended consequences of secondary legislation: A case study of the UK landfill tax (qualifying fines) order 2015. Resour. Conserv. Recycl. 2018, 138, 160-171. [CrossRef]

39. Skawińska, E.; Zalewski, R.I. Circular economy as a management model in the paradigm of sustainable development. Management 2018, 22, 217-233. [CrossRef]

40. Zu Ermgassen, E.K.; Kelly, M.; Bladon, E.; Salemdeeb, R.; Balmford, A. support amongst UK pig farmers and agricultural stakeholders for the use of food losses in animal feed. PLOS ONE 2018, 13, e0196288. [CrossRef]

41. Llorente-González, L.J.; Vence, X. Decoupling or 'decaffing'? The underlying conceptualization of Circular Economy in the European Union Monitoring Framework. Sustainability 2019, 11, 4898. [CrossRef]

42. Jiménez-Rivero, A.; García-Navarro, J. Exploring factors influencing post-consumer gypsum recycling and landfilling in the European Union. Resour. Conserv. Recycl. 2017, 116, 116-123. [CrossRef]

43. Termeer, C.; Metze, T. More than peanuts: Transformation towards a circular economy through a small-wins governance framework. J. Clean. Prod. 2019, 240, 118272. [CrossRef]

44. Maitre-Ekern, E.; Dalhammar, C. Regulating planned obsolescence: A review of legal approaches to increase Product Durability and Reparability in Europe. Rev. Eur. Comp. Int. Environ. Law 2016, 25, 378-394. [CrossRef]

45. Milios, L. Advancing to a Circular Economy: Three essential ingredients for a comprehensive policy mix. Sustain. Sci. 2017, 13, 861-878. [CrossRef] [PubMed]

46. Aceleanu, M.I.; Serban, A.C.; Suciu, M.-C.; Bitoiu, T.I. The management of municipal waste through circular economy in the context of smart cities development. IEEE Access 2019, 7, 133602-133614. [CrossRef]

47. Sakai, S.; Yoshida, H.; Hirai, Y.; Asari, M.; Takigami, H.; Takahashi, S.; Tomoda, K.; Peeler, M.V.; Wejchert, J.; Schmid-Unterseh, T.; et al. International comparative study of 3R and waste management policy developments. J. Mater. Cycles Waste Manag. 2011, 13, 86-102. [CrossRef]

48. Cesaro, A.; Marra, A.; Kuchta, K.; Belgiorno, V.; Van Hullebusch, E.D. WEEE management in a circular economy perspective: An overview. Glob. NEST J. 2018, 20, 743-750. [CrossRef]

49. Faraca, G.; Martinez-Sanchez, V.; Astrup, T.F. Environmental life cycle cost assessment: Recycling of hard plastic waste collected at Danish recycling centres. Resour. Conserv. Recycl. 2019, 143, 299-309. [CrossRef]

50. Foschi, E.; Bonoli, A. The Commitment of Packaging Industry in the Framework of the European Strategy for Plastics in a Circular Economy. Adm. Sci. 2019, 9, 18. [CrossRef]

51. Groh, K.J.; Backhaus, T.; Almroth, B.C.; Geueke, B.; A Inostroza, P.; Lennquist, A.; Leslie, H.A.; Maffini, M.; Slunge, D.; Trasande, L.; et al. Overview of known plastic packaging-associated chemicals and their hazards. Sci. Total Environ. 2019, 651, 3253-3268. [CrossRef]

52. Misso, R.; Varlese, M. Agri-food, plastic and sustainability. Qual.-Access Success 2018, 19, 324-330.

53. Rhodes, C.J. Plastic pollution and potential solutions. Sci. Prog. 2018, 101, 207-260. [CrossRef]

54. Pauer, E.; Wohner, B.; Heinrich, V.; Tacker, M. Assessing the environmental sustainability of food packaging: An extended life cycle assessment including packaging-related food losses and waste and circularity assessment. Sustainability 2019, 11, 925. [CrossRef]

55. Warrings, R.; Fellner, J. Management of aluminium packaging waste in selected European countries. Waste Manag. Res. 2019, 37, 357-364. [CrossRef] [PubMed]

56. Faraca, G.; Tonini, D.; Astrup, T.F. Dynamic accounting of greenhouse gas emissions from cascading utilisation of wood waste. Sci. Total Environ. 2019, 651, 2689-2700. [CrossRef] [PubMed]

57. Faussone, G.C. Transportation fuel from plastic: Two cases of study. Waste Manag. 2018, 73, $416-423$. [CrossRef]

58. Gallego-Schmid, A.; Mendoza, J.M.F.; Azapagic, A. Environmental assessment of microwaves and the effect of European energy efficiency and waste management legislation. Sci. Total Environ. 2018, 618, 487-499. [CrossRef]

59. Nowakowski, P.; Król, A.; Mrówczyńska, B. Supporting mobile WEEE collection on demand: A method for multi-criteria vehicle routing, loading and cost optimisation. Waste Manag. 2017, 69, 377-392. [CrossRef]

60. Unger, N.; Beigl, P.; Höggerl, G.; Salhofer, S. The greenhouse gas benefit of recycling waste electrical and electronic equipment above the legal minimum requirement: An Austrian LCA case study. J. Clean. Prod. 2017, 164, 1635-1644. [CrossRef] 
61. Gigli, S.; Landi, D.; Germani, M. Cost-benefit analysis of a circular economy project: A study on a recycling system for end-of-life tyres. J. Clean. Prod. 2019, 229, 680-694. [CrossRef]

62. Saidani, M.; Yannou, B.; Leroy, Y.; Cluzel, F. Heavy vehicles on the road towards the circular economy: Analysis and comparison with the automotive industry. Resour. Conserv. Recycl. 2018, 135, 108-122. [CrossRef]

63. Grandjean, T.R.; Groenewald, J.; Marco, J. The experimental evaluation of lithium ion batteries after flash cryogenic freezing. J. Energy Storage 2019, 21, 202-215. [CrossRef]

64. Grandjean, T.R.; Groenewald, J.; McGordon, A.; Marco, J. Cycle life of lithium ion batteries after flash cryogenic freezing. J. Energy Storage 2019, 24. [CrossRef]

65. Koszewska, M. Circular Economy-Challenges for the Textile and Clothing Industry. Autex Res. J. 2018, 18, 337-347. [CrossRef]

66. Lopes, M.; Miranda, S.; Alves, J.M.; Pereira, A.S.; Belo, I. Waste Cooking Oils as Feedstock for Lipase and Lipid-Rich Biomass Production. Eur. J. Lipid Sci. Technol. 2018, 121, 1800188. [CrossRef]

67. Mendoza, J.M.F.; D’Aponte, F.; Gualtieri, D.; Azapagic, A. Disposable baby diapers: Life cycle costs, eco-efficiency and circular economy. J. Clean. Prod. 2019, 211, 455-467. [CrossRef]

68. Mustonen, K.; Deviatkin, I.; Havukainen, J.; Horttanainen, M. Nitrogen behaviour during thermal drying of mechanically dewatered biosludge from pulp and paper industry. Environ. Technol. 2017, 39, 1052-1060. [CrossRef]

69. Peiró, L.T.; Ardente, F.; Mathieux, F. Design for Disassembly Criteria in EU Product Policies for a More Circular Economy: A Method for Analyzing Battery Packs in PC-Tablets and Subnotebooks. J. Ind. Ecol. 2017, 21, 731-741. [CrossRef]

70. Jiménez-Rivero, A.; García-Navarro, J. Best practices for the management of end-of-life gypsum in a circular economy. J. Clean. Prod. 2017, 167, 1335-1344. [CrossRef]

71. Paredes-Sánchez, J.P.; López-Ochoa, L.M.; López, L.M.; Las-Heras-Casas, J.; Xiberta-Bernat, J. Evolution and perspectives of the bioenergy applications in Spain. J. Clean. Prod. 2019, 213, 553-568. [CrossRef]

72. Álvarez-de Prado, L.; De Simón-Martín, M.; Diez-Suárez, A.-M.; Blanes-Peiró, J.J.; González-Martínez, A. Optimal Sizing and Location of Co-Digestion Power Plants in Spain through a GIS-Based Approach. Environments 2018, 5, 137. [CrossRef]

73. Blanc, S.; Massaglia, S.; Brun, F.; Peano, C.; Mosso, A.; Giuggioli, N.R. Use of Bio-Based Plastics in the Fruit Supply Chain: An Integrated Approach to Assess Environmental, Economic, and Social Sustainability. Sustainability 2019, 11, 2475. [CrossRef]

74. Briassoulis, D.; Pikasi, A.; Hiskakis, M. End-of-waste life: Inventory of alternative end-of-use recirculation routes of bio-based plastics in the European Union context. Crit. Rev. Environ. Sci. Technol. 2019, 49, 1835-1892. [CrossRef]

75. Fellner, J.; Laner, D.; Warrings, R.; Schustereder, K.; Lederer, J. Potential Impacts of the EU circular economy package on the utilization of secondary resources. Detritus 2018, 2, 16. [CrossRef]

76. Haas, W.; Krausmann, F.; Wiedenhofer, D.; Heinz, M. How Circular is the Global Economy? An Assessment of Material Flows, Waste Production, and Recycling in the European Union and the World in 2005. J. Ind. Ecol. 2015, 19, 765-777. [CrossRef]

77. Jacobi, N.; Haas, W.; Wiedenhofer, D.; Mayer, A. Providing an economy-wide monitoring framework for the circular economy in Austria: Status quo and challenges. Resour. Conserv. Recycl. 2018, 137, 156-166. [CrossRef]

78. Pieratti, E.; Paletto, A.; De Meo, I.; Fagarazzi, C.; Migliorini, M.G.R. Assessing the forest-wood chain at local level: A Multi-Criteria Decision Analysis (MCDA) based on the circular bioeconomy principles. Ann. For. Res. 2019, 62, 123-138. [CrossRef]

79. Mayer, A.; Haas, W.; Wiedenhofer, D.; Krausmann, F.; Nuss, P.; Blengini, G.A. Measuring Progress towards a Circular Economy: A Monitoring Framework for Economy-wide Material Loop Closing in the EU28. J. Ind. Ecol. 2018, 23, 62-76. [CrossRef]

80. Halkos, G.E.; Petrou, K.N. Assessing 28 EU member states' environmental efficiency in national waste generation with DEA. J. Clean. Prod. 2019, 208, 509-521. [CrossRef]

81. Husgafvel, R.; Karjalainen, E.; Linkosalmi, L.; Dahl, O. Recycling industrial residue streams into a potential new symbiosis product-The case of soil amelioration granules. J. Clean. Prod. 2016, 135, 90-96. [CrossRef] 
82. Jiménez-Rivero, A.; Sathre, R.; Navarro, J.G. Life cycle energy and material flow implications of gypsum plasterboard recycling in the European Union. Resour. Conserv. Recycl. 2016, 108, 171-181. [CrossRef]

83. McMahon, K.; Fitzpatrick, C.; Johnson, M. Enabling preparation for re-use of waste electrical and electronic equipment in Ireland: Lessons from other EU member states. J. Clean. Prod. 2019, 232, 1005-1017. [CrossRef]

84. Saidani, M.; Kendall, A.; Yannou, B.; Leroy, Y.; Cluzel, F. Closing the loop on platinum from catalytic converters: Contributions from material flow analysis and circularity indicators. J. Ind. Ecol. 2019, 23, 1143-1158. [CrossRef]

85. Gomes, L.A.; Gabriel, N.; Gando-Ferreira, L.M.; Góis, J.C.; Quina, M.J. Analysis of potentially toxic metal constraints to apply sewage sludge in Portuguese agricultural soils. Environ. Sci. Pollut. Res. 2019, 26, 26000-26014. [CrossRef] [PubMed]

86. Lopez-Uceda, A.; Galvín, A.; Ayuso, J.; Jiménez, J.R.; Vanwalleghem, T.; Peña, A. Risk assessment by percolation leaching tests of extensive green roofs with fine fraction of mixed recycled aggregates from construction and demolition waste. Environ. Sci. Pollut. Res. 2018, 25, 36024-36034. [CrossRef] [PubMed]

87. Obersteg, A.; Arlati, A.; Acke, A.; Berruti, G.; Czapiewski, K.; Dąbrowski, M.; Heurkens, E.; Mezei, C.; Palestino, M.F.; Varjú, V.; et al. Urban Regions Shifting to Circular Economy: Understanding Challenges for New Ways of Governance. Urban Plan. 2019, 4, 19-31. [CrossRef]

88. Tomić, T.; Schneider, D.R. Municipal solid waste system analysis through energy consumption and return approach. J. Environ. Manag. 2017, 203, 973-987. [CrossRef]

89. Uche-Soria, M.; Rodríguez-Monroy, C. Solutions to Marine Pollution in Canary Islands' ports: Alternatives and Optimization of Energy Management. Resources 2019, 8, 59. [CrossRef]

90. Tisserant, A.; Pauliuk, S.; Merciai, S.; Schmidt, J.; Fry, J.; Wood, R.; Tukker, A. Solid Waste and the Circular Economy: A Global Analysis of Waste Treatment and Waste Footprints. J. Ind. Ecol. 2017, 21, 628-640. [CrossRef]

91. Uche-Soria, M.; Rodríguez-Monroy, C. An Efficient Waste-To-Energy Model in Isolated Environments. Case Study: La Gomera (Canary Islands). Sustainability 2019, 11, 3198. [CrossRef]

92. Traven, L.; Kegalj, I.; Šebelja, I. Management of municipal solid waste in Croatia: Analysis of current practices with performance benchmarking against other European Union member states. Waste Manag. Res. 2018, 36, 663-669. [CrossRef]

93. Pires, A.; Martinho, G. Waste hierarchy index for circular economy in waste management. Waste Manag. 2019, 95, 298-305. [CrossRef]

94. Quina, M.J.; Bontempi, E.; Bogush, A.; Schlumberger, S.; Weibel, G.; Braga, R.; Funari, V.; Hyks, J.; Rasmussen, E.; Lederer, J. Technologies for the management of MSW incineration ashes from gas cleaning: New perspectives on recovery of secondary raw materials and circular economy. Sci. Total Environ. 2018, 635, 526-542. [CrossRef] [PubMed]

95. Ribic, B.; Voca, N.; Ilakovac, B. Concept of sustainable waste management in the city of Zagreb: Towards the implementation of circular economy approach. J. Air Waste Manag. Assoc. 2016, 67, 241-259. [CrossRef] [PubMed]

96. Taušová, M.; Mihaliková, E.; Čulková, K.; Stehlíková, B.; Tauš, P.; Kudelas, D.; Štrba, L'. Recycling of Communal Waste: Current State and Future Potential for Sustainable Development in the EU. Sustainability 2019, 11, 2904. [CrossRef]

97. Bausys, R.; Cavallaro, F.; Semenas, R. Application of Sustainability Principles for Harsh Environment Exploration by Autonomous Robot. Sustainability 2019, 11, 2518. [CrossRef]

98. Moraga, G.; Huysveld, S.; Mathieux, F.; Blengini, G.A.; Alaerts, L.; Van Acker, K.; De Meester, S.; Dewulf, J. Circular economy indicators: What do they measure? Resour. Conserv. Recycl. 2019, 146, 452-461. [CrossRef]

99. Rossetti, M.; Bin, A. Development of soundproofing and sound-absorbing bituminous membranes containing recycled materials. Techne 2018, 16, 281-288. [CrossRef]

100. Brandoni, C.; Bošnjaković, B. Energy, food and water nexus in the European Union: Towards a circular economy. Proc. Inst. Civ. Eng. Energy 2018, 171, 140-144. [CrossRef]

101. Van Raamsdonk, L.W.D.; Van Der Fels-Klerx, H.J.; De Jong, J. New feed ingredients: The insect opportunity. Food Addit. Contam. Part A 2017, 34, 1384-1397. [CrossRef]

102. Egea, F.J.; Torrente, R.G.; Aguilar, A. An efficient agro-industrial complex in Almería (Spain): Towards an integrated and sustainable bioeconomy model. New Biotechnol. 2018, 40, 103-112. [CrossRef] 
103. Nerini, F.F.; Slob, A.; Engström, R.E.; Trutnevyte, E. A Research and Innovation Agenda for Zero-Emission European Cities. Sustainability 2019, 11, 1692. [CrossRef]

104. Fonseca, L.M.; Portela, A.R.; Duarte, B.; Queirós, J.; Paiva, L. Mapping higher education for sustainable development in Portugal. Manag. Mark. 2018, 13, 1064-1075. [CrossRef]

105. Smol, M.; Kulczycka, J. Towards innovations development in the European raw material sector by evolution of the knowledge triangle. Resour. Policy 2019, 62, 453-462. [CrossRef]

106. Mengal, P.; Wubbolts, M.; Zika, E.; Ruiz, A.; Brigitta, D.; Pieniadz, A.; Black, S. Bio-based Industries Joint Undertaking: The catalyst for sustainable bio-based economic growth in Europe. New Biotechnol. 2018, 40, 31-39. [CrossRef] [PubMed]

107. Pivnenko, K.; Laner, D.; Astrup, T.F. Dynamics of bisphenol A (BPA) and bisphenol S (BPS) in the European paper cycle: Need for concern? Resour. Conserv. Recycl. 2018, 133, 278-287. [CrossRef]

108. Popp, J.; Olah, J.; Kiss, A.; Temesi, A.; Fogarassy, C.; Lakner, Z. The socio-economic force field of the creation of short food supply chains in Europe. J. Food Nutr. Res. 2019, 58, 31-41.

109. Rodrigues, M.; Franco, M. Measuring the urban sustainable development in cities through a Composite Index: The case of Portugal. Sustain. Dev. 2019, 28, 507-520. [CrossRef]

110. Vaverková, M.D. Landfill Impacts on the Environment. Geosciences 2019, 9, 431. [CrossRef]

111. Antón, J.M.R.; Rubio, L.; Celemín-Pedroche, M.S.; Alonso-Almeida, M.D.M. Analysis of the relations between circular economy and sustainable development goals. Int. J. Sustain. Dev. World Ecol. 2019, 26, 708-720. [CrossRef]

112. Sapmaz, V.E. The recent measures and the strategies of the EU member states towards circular economy transition. Ank. Avrupa Calismalari Derg. 2018, 17, 463-488.

113. Trica, C.L.; Banacu, C.S.; Busu, M. Environmental Factors and Sustainability of the Circular Economy Model at the European Union Level. Sustainability 2019, 11, 1114. [CrossRef]

114. Bassi, F.; Dias, J.G. The use of circular economy practices in SMEs across the EU. Resour. Conserv. Recycl. 2019, 146, 523-533. [CrossRef]

115. Cole, C.; Gnanapragasam, A.; Cooper, T.; Singh, J. An assessment of achievements of the WEEE Directive in promoting movement up the waste hierarchy: Experiences in the UK. Waste Manag. 2019, 87, 417-427. [CrossRef] [PubMed]

116. Belaud, J.-P.; Adoue, C.; Vialle, C.; Chorro, A.; Sablayrolles, C. A circular economy and industrial ecology toolbox for developing an eco-industrial park: Perspectives from French policy. Clean Technol. Environ. Policy 2019, 21, 967-985. [CrossRef]

117. Frone, D.F.; Frone, S. Eco-Innovation Park Promoting the Green Economy in Romania. Sci. Pap.-Ser. Manag. Econ. Eng. Agric. Rural Dev. 2017, 17, 111-119.

118. Patricio, J.; Axelsson, L.; Blomé, S.; Rosado, L. Enabling industrial symbiosis collaborations between SMEs from a regional perspective. J. Clean. Prod. 2018, 202, 1120-1130. [CrossRef]

119. Cervo, H.; Ferrasse, J.-H.; Descales, B.; Van Eetvelde, G. Blueprint: A methodology facilitating data exchanges to enhance the detection of industrial symbiosis opportunities-Application to a refinery. Chem. Eng. Sci. 2020, 211, 115254. [CrossRef]

120. Busu, M.; Trica, C.L. Sustainability of Circular Economy Indicators and Their Impact on Economic Growth of the European Union. Sustainability 2019, 11, 5481. [CrossRef]

121. Vuta, M.; Vuta, M.; Enciu, A.; Cioaca, S.-I. Assessment of the Circular Economy's Impact in the EU Economic Growth. Amfiteatru Econ. 2018, 20, 248-261. [CrossRef]

122. Halkos, G.E.; Petrou, K.N. Analysing the Energy Efficiency of EU Member States: The Potential of Energy Recovery from Waste in the Circular Economy. Energies 2019, 12, 3718. [CrossRef]

123. Caruso, M.C.; Braghieri, A.; Capece, A.; Napolitano, F.; Romano, P.; Galgano, F.; Altieri, G.; Genovese, F. Recent Updates on the Use of Agro-Food Waste for Biogas Production. Appl. Sci. 2019, 9, 1217. [CrossRef]

124. Huygens, D.; Saveyn, H.G.M. Agronomic efficiency of selected phosphorus fertilisers derived from secondary raw materials for European agriculture. A meta-analysis. Agron. Sustain. Dev. 2018, 38, 52. [CrossRef]

125. Kominko, H.; Gorazda, K.; Wzorek, Z.; Wojtas, K. Sustainable Management of Sewage Sludge for the Production of Organo-Mineral Fertilizers. Waste Biomass Valorization 2017, 9, 1817-1826. [CrossRef]

126. Kupczyk, A.; Kołecka, K.; Gajewska, M.H. Solving the Beach Wrack Problems by On Site Treatment with Reed Beds Towards Fertilizer Amendments. J. Ecol. Eng. 2019, 20, 252-261. [CrossRef] 
127. Mosquera-Losada, M.; Amador-García, A.; Muñoz-Ferreiro, N.; Santiago-Freijanes, J.J.; Ferreiro-Domínguez, N.; Romero-Franco, R.; Rigueiro-Rodríguez, A. Sustainable use of sewage sludge in acid soils within a circular economy perspective. Catena 2017, 149, 341-348. [CrossRef]

128. Smol, M.; Kulczycka, J.; Kowalski, Z. Sewage sludge ash (SSA) from large and small incineration plants as a potential source of phosphorus-Polish case study. J. Environ. Manag. 2016, 184, 617-628. [CrossRef]

129. Markou, G.; Arapoglou, D.; Eliopoulos, C.; Balafoutis, A.; Taddeo, R.; Panara, A.; Thomaidis, N. Cultivation and safety aspects of Arthrospira platensis (Spirulina) grown with struvite recovered from anaerobic digestion plant as phosphorus source. Algal Res. 2019, 44, 101716. [CrossRef]

130. Smol, M.; Kulczycka, J.; Henclik, A.; Gorazda, K.; Wzorek, Z. The possible use of sewage sludge ash (SSA) in the construction industry as a way towards a circular economy. J. Clean. Prod. 2015, 95, 45-54. [CrossRef]

131. Wong, Y.C.; Al-Obaidi, K.M.; Mahyuddin, N. Recycling of end-of-life vehicles (ELVs) for building products: Concept of processing framework from automotive to construction industries in Malaysia. J. Clean. Prod. 2018, 190, 285-302. [CrossRef]

132. Katz-Gerro, T.; López-Sintas, J. Mapping circular economy activities in the European Union: Patterns of implementation and their correlates in small and medium-sized enterprises. Bus. Strategy Environ. 2018, 28, 485-496. [CrossRef]

133. Silva, F.C.; Shibao, F.Y.; Kruglianskas, I.; Barbieri, J.C.; Sinisgalli, P.A.D.A. Circular economy: Analysis of the implementation of practices in the Brazilian network. Revista de Gestão 2019, 26, 39-60. [CrossRef]

134. Andronie, M.; Simion, V.-E.; Gurgu, E.; Dijmǵrescu, A.; Dijmǵrescu, I.A. Social Responsibility of Firms and the Impact of Bio-Economy in Intelligent Use of Renewable Energy Source. Amfiteatru Econ. 2019, 21, 520-535. [CrossRef]

135. Colombo, L.A.; Pansera, M.; Owen, R.R. The discourse of eco-innovation in the European Union: An analysis of the Eco-Innovation Action Plan and Horizon 2020. J. Clean. Prod. 2019, 214, 653-665. [CrossRef]

136. Dimić-Mišić, K.; Barceló, E.; Brkic, V.S.; Gane, P. Identifying the challenges of implementing a European bioeconomy based on forest resources: Reality demands circularity. FME Trans. 2019, 47, 60-69. [CrossRef]

137. Cretu, R.F.; Cretu, R.C.; Voinea-Mic, C.C.; Stefan, P. Circular economy, green buildings and environmental protection. Qual.-Access Success 2019, 20, 220-226.

138. Dupont-Inglis, J.; Borg, A. Destination bioeconomy-The path towards a smarter, more sustainable future. New Biotechnol. 2018, 40, 140-143. [CrossRef]

139. Hamelin, L.; Borzecka-Walker, M.; Kozak, M.; Pudełko, R. A spatial approach to bioeconomy: Quantifying the residual biomass potential in the EU-27. Renew. Sustain. Energy Rev. 2019, 100, 127-142. [CrossRef]

140. Leipold, S.; Petit-Boix, A. The circular economy and the bio-based sector-Perspectives of European and German stakeholders. J. Clean. Prod. 2018, 201, 1125-1137. [CrossRef]

141. Unay-Gailhard, I.; Bojnec, Š. The impact of green economy measures on rural employment: Green jobs in farms. J. Clean. Prod. 2019, 208, 541-551. [CrossRef]

142. Lesakova, L. Small and medium enterprises and eco-innovations: Empirical study of Slovak SME's. Mark. Manag. Innov. 2019, 89-97. [CrossRef]

143. Sastre-Centeno, J.M.; Galiana, M.E.I. La economía colaborativa: Un nuevo modelo económico. CIRIEC-España, Revista de Economía Pública, Social y Cooperativa 2019, 94, 219-250. [CrossRef]

144. Veleva, V.; Bodkin, G. Corporate-entrepreneur collaborations to advance a circular economy. J. Clean. Prod. 2018, 188, 20-37. [CrossRef]

145. Polverini, D.; Miretti, U. An approach for the techno-economic assessment of circular economy requirements under the Ecodesign Directive. Resour. Conserv. Recycl. 2019, 150. [CrossRef]

146. Richter, J.L.; Van Buskirk, R.; Dalhammar, C.; Bennich, P. Optimal durability in least life cycle cost methods: The case of LED lamps. Energy Effic. 2018, 12, 107-121. [CrossRef]

147. De Jesus, A.; Antunes, P.; Santos, R.; Mendonça, S. Eco-innovation pathways to a circular economy: Envisioning priorities through a Delphi approach. J. Clean. Prod. 2019, 228, 1494-1513. [CrossRef]

148. Kirchherr, J.; Piscicelli, L.; Bour, R.; Kostense-Smit, E.; Muller, J.; Huibrechtse-Truijens, A.; Hekkert, M. Barriers to the Circular Economy: Evidence From the European Union (EU). Ecol. Econ. 2018, 150, $264-272$. [CrossRef]

149. Ferronato, N.; Rada, E.C.; Portillo, M.A.G.; Cioca, L.I.; Ragazzi, M.; Torretta, V. Introduction of the circular economy within developing regions: A comparative analysis of advantages and opportunities for waste valorization. J. Environ. Manag. 2018, 230, 366-378. [CrossRef] 
150. Ghisellini, P.; Cialani, C.; Ulgiati, S. A review on circular economy: The expected transition to a balanced interplay of environmental and economic systems. J. Clean. Prod. 2016, 114, 11-32. [CrossRef]

151. McDowall, W.; Geng, Y.; Huang, B.; Barteková, E.; Bleischwitz, R.; Türkeli, S.; Kemp, R.; Doménech, T. Circular Economy Policies in China and Europe. J. Ind. Ecol. 2017, 21, 651-661. [CrossRef]

152. Ziegler, R. Viewpoint-Water innovation for a circular economy: The contribution of grassroots actors. Water Altern. 2019, 12, 774-787.

153. van Eck, N.J.; Waltman, L. VOSviewer Manual. Available online: https://www.vosviewer.com/documentation/ Manual_VOSviewer_1.6.13.pdf (accessed on 16 December 2019).

154. Alhola, K.; Ryding, S.-O.; Salmenperä, H.; Busch, N.J. Exploiting the Potential of Public Procurement: Opportunities for Circular Economy. J. Ind. Ecol. 2018, 23, 96-109. [CrossRef]

155. Bressanelli, G.; Perona, M.; Saccani, N. Challenges in supply chain redesign for the Circular Economy: A literature review and a multiple case study. Int. J. Prod. Res. 2018, 57, 7395-7422. [CrossRef]

156. Corona, B.; Shen, L.; Reike, D.; Carreón, J.R.; Worrell, E. Towards sustainable development through the circular economy-A review and critical assessment on current circularity metrics. Resour. Conserv. Recycl. 2019, 151, 104498. [CrossRef]

157. Kyriakopoulos, G.L.; Kapsalis, V.C.; Aravossis, K.; Zamparas, M.; Mitsikas, A. Evaluating Circular Economy under a Multi-Parametric Approach: A Technological Review. Sustainability 2019, 11, 6139. [CrossRef]

158. Sassanelli, C.; Rosa, P.; Rocca, R.; Terzi, S. Circular economy performance assessment methods: A systematic literature review. J. Clean. Prod. 2019, 229, 440-453. [CrossRef]

159. Jabbour, C.J.C.; Sarkis, J.; Jabbour, A.B.L.D.S.; Renwick, D.W.; Singh, S.K.; Grebinevych, O.; Kruglianskas, I.; Filho, M.G. Who is in charge? A review and a research agenda on the 'human side' of the circular economy. J. Clean. Prod. 2019, 222, 793-801. [CrossRef]

160. Kalmykova, Y.; Sadagopan, M.; Rosado, L. Circular economy-From review of theories and practices to development of implementation tools. Resour. Conserv. Recycl. 2018, 135, 190-201. [CrossRef]

(C) 2020 by the authors. Licensee MDPI, Basel, Switzerland. This article is an open access article distributed under the terms and conditions of the Creative Commons Attribution (CC BY) license (http://creativecommons.org/licenses/by/4.0/). 